\title{
UNCERTAINTY, LONG-RUN, AND MONETARY POLICY RISKS IN A TWO-COUNTRY MACRO MODEL
}

\author{
Kimberly A. Berg
}

Nelson C. Mark

Working Paper 27844

http://www.nber.org/papers/w27844

\author{
NATIONAL BUREAU OF ECONOMIC RESEARCH \\ 1050 Massachusetts Avenue \\ Cambridge, MA 02138 \\ September 2020
}

The views expressed herein are those of the authors and do not necessarily reflect the views of the National Bureau of Economic Research.

NBER working papers are circulated for discussion and comment purposes. They have not been peer-reviewed or been subject to the review by the NBER Board of Directors that accompanies official NBER publications.

(C) 2020 by Kimberly A. Berg and Nelson C. Mark. All rights reserved. Short sections of text, not to exceed two paragraphs, may be quoted without explicit permission provided that full credit, including (c) notice, is given to the source. 
Uncertainty, Long-Run, and Monetary Policy Risks in a Two-Country Macro Model

Kimberly A. Berg and Nelson C. Mark

NBER Working Paper No. 27844

September 2020

JEL No. E21,E43,F31,G12

\begin{abstract}
$\underline{\text { ABSTRACT }}$
We study international currency risk in a two-country dynamic stochastic general equilibrium model under incomplete markets. The underlying sources of risk are direct shocks to productivity growth, shocks to a long-run risk component of productivity growth, shocks to a stochastic volatility component of productivity growth, and shocks to monetary policy. The long-run risk and stochastic volatility shocks have the interpretation of aggregate demand shocks. Crosscountry heterogeneity in the model arises from three sources: differences in the long-run risk and stochastic volatility process parameters that we estimate using United States and Japanese total factor productivity data, differences in monetary policy parameters, and differences in export pricing. The driving force behind currency risk is heterogeneity in precautionary saving. Differences in monetary policy can generate moderate currency risk, but structural differences in productivity growth are more important. Export pricing conventions are not important sources of currency risk. Stochastic volatility shocks are key to generating volatility in the currency risk premium, but they do not help at all in explaining the forward premium bias/anomaly.
\end{abstract}

\author{
Kimberly A. Berg \\ Department of Economics \\ Miami University \\ Oxford, OH 45056 \\ bergka@miamioh.edu \\ Nelson C. Mark \\ Department of Economics \\ 3060 Jenkins-Nanovic Hall \\ University of Notre Dame \\ Notre Dame, IN 46556 \\ and NBER \\ nmark@nd.edu
}




\section{Introduction}

We study international currency risk in a two-country dynamic stochastic general equilibrium (DSGE) model under incomplete markets. The underlying sources of risk are direct shocks to productivity growth, shocks to a long-run risk component of productivity growth, shocks to a stochastic volatility component of productivity growth, and shocks to monetary policy. Stochastic volatility shocks and long-run risk shocks can be viewed as aggregate demand shocks. Currency risk only emerges under structural cross-country heterogeneity. The heterogeneity we examine is due to empirically motivated differences in the long-run risk and stochastic volatility parameters governing productivity growth, differences in the conduct of monetary policy, and differences in export pricing practices. We find that differences in monetary policy generate moderate currency risk, but structural differences in productivity growth are potentially more important. Export pricing conventions-the currency in which export prices are set-are not important sources of currency risk. Stochastic volatility shocks are key to generating volatility in the currency risk premium, but they do not help at all in explaining the forward premium bias/anomaly 1

Agents in the model have recursive utility (Epstein and Zin (1989) and Weil (1989)). The specific functional form we use is from Swanson (2019). Export pricing by producer currency pricing $(\mathrm{PCP})$, local currency pricing (LCP), and dominant currency pricing (DCP) are evaluated. The parameters of the long-run risk and stochastic volatility processes are estimated from total factor productivity growth for the United States and Japan. We choose the United States because the U. S. dollar typically serves as the dominant currency under DCP and Japan because the Japanese yen is a typical funding currency in the carry trade. In the model, we refer to country 1 as the United States and country 2 as Japan. Also in the model, currency risk and the compensation for bearing that risk are measured by the strength of the forward premium bias/anomaly, the currency excess return from shorting the Japanese yen and going long the U.S. dollar, and the carry trade excess return. We also examine the extent to which the model explains the consumption correlation puzzle (Backus et al. (1992)) and the Backus and Smith (1993) puzzle, which are auxiliary markers of risk sharing (or lack thereof).

The primary mechanism driving the currency risk premium in our model is differential precautionary saving. A relatively more procyclical monetary policy in Japan, for example, stabilizes its economy relative to the United States. The higher economic volatility in the United States relative to Japan raises the desire for precautionary saving by people in the United States who want to go long U.S. dollar denominated bonds. An excess return from shorting the Japanese yen denominated bonds and using the proceeds to go long the U.S. dollar denominated bonds emerges. As in Ready et al. (2017), and perhaps a bit unintuitively, the relatively stable country

\footnotetext{
${ }^{1}$ Popularized by Fama (1984), the forward premium bias refers to a slope coefficient, from regressing the one-step ahead change in the log country 1 price of country 2's currency on the interest rate differential between countries 1 and 2, that lies between zero and one. The forward premium anomaly refers to when the slope coefficient is negative. We refer to this regression as the Fama regression and the slope as $\beta_{\text {Fama }}$.
} 
(Japan) pays the currency risk premium. One might think that because the stable country is safe, its currency would serve as a hedge asset and earn a negative excess return. Instead, the relatively stable country tends to pay the excess return.

We first show that export pricing conventions (PCP, LCP, and DCP) are not significant drivers of currency risk. If you set identical parameters for monetary policy rules and productivity growth in both countries, the model generates minuscule carry trade and currency excess returns, and a small forward premium bias, regardless of the currency in which export prices are set. Setting Japan's monetary policy to be relatively more procyclical (increasing its interest rate responsiveness to the output gap) while keeping the productivity process parameters symmetric across countries substantially decreases the excess return from shorting the Japanese yen and going long the U.S. dollar (Japan pays the premium). This confirms a key result from Backus et al. (2020)'s complete markets endowment model. Their mechanism was that Japan's relatively more procyclical monetary policy increases Japan's inflation risk by lowering the correlation between consumption and inflation. The increased inflation risk also occurs in our model, but we have the added mechanism of monetary policy stabilization, which is absent in Backus et al. (2020) because their exogenous consumption growth is unaffected by monetary policy. Backus et al. (2020)'s second main result is that if Japan's monetary policy is relatively more accommodating to inflation (the inflation response coefficient is lower than that for the United States), it will further affect the joint consumption-inflation dynamics by lowering the correlation, and in their model, reinforces the excess return. In our production model, however, we get the opposite result. Relative inflation accommodation in Japan's monetary policy has a trivial effect on Japan's consumption-inflation correlation, but, it is destabilizing in that it increases output growth volatility. This increases the desire for precautionary saving by people in Japan. Instead of Japan paying the currency risk premium as in Backus et al. (2020), the United States pays the premium. The extent of cross-country monetary policy heterogeneity that we investigate generates a modest currency risk premium and forward premium bias, but does not bring about the forward premium anomaly.

We next investigate the role of real cross-country heterogeneity. We show that empirically motivated heterogeneity in the productivity growth process is an important source of currency risk-potentially more important than reasonable differences in monetary policy. In the data, Japan's productivity growth is more volatile than the United States. We estimate a long-run risk and stochastic volatility process for productivity growth for both countries. We introduce productivity heterogeneity by setting the productivity parameters equal to the country estimates. If monetary policy is kept symmetric across countries, the currency risk premium paid by the United States becomes reasonably large (1.52\% per annum under DCP), and generates the forward premium anomaly, with a Fama slope coefficient of -1.37 (under DCP).

While the model shows variation in export pricing conventions (LCP, PCP, or DCP) does not matter for currency risk, it does matter for trade-related variables (terms of trade and balance 
of trade), especially in response to monetary policy shocks. This is why Gopinath et al. (2020)'s paper on DCP focuses on the effect of monetary policy shocks on trade variables. We find that long-run risk shocks in our model can be interpreted as aggregate demand shocks in the sense that a positive shock raises output and inflation. Long-run risk shocks also contribute towards explaining the forward premium bias/anomaly. Stochastic volatility shocks in our model, as in $\mathrm{Xu}(2016)$ and Leduc and Liu (2016), are also aggregate demand shocks in the sense that an increase in uncertainty depresses output and inflation. Stochastic volatility shocks also make a large contribution to currency risk premium volatility, but they do not help to explain the forward premium bias.

The model has several other qualities that are generally consistent with the data. Crosscountry correlations of consumption growth are very low (near zero) and under DCP and LCP, lie below cross-country output growth correlations. The implied risk-sharing index is in the range computed by Brandt et al. (2006). The real exchange rate depreciation is very highly correlated with the nominal exchange rate depreciation (correlation is -0.936 under DCP). However, the model does fall short in certain dimensions. Most notably, it cannot generate enough volatility in inflation and the exchange rate depreciation.

The remainder of the paper is as follows. The next section discusses related literature. Section 2 provides a brief presentation of the model. Section 3 reports our estimates of the productivity growth processes for the United States and Japan. The features of the data that we focus on explaining are presented in Section 4. The main results from the model are presented in Section 5 and Section 6 concludes.

\section{Related Literature}

In terms of investigating the role of monetary policy, we draw comparisons to Backus et al. (2020). They study how cross-country differences in monetary policy create currency risk in a two-country, complete markets, endowment model where exogenous consumption growth is driven by a longrun risk and stochastic volatility process. They present two elegant and important results-Japan pays the currency risk premium if Japan's monetary policy is relatively a) more procyclical or b) more accommodating to inflation. We confirm that their first result also holds in a production economy, but their second result does not. We discuss these points further below.

In terms of investigating the importance of real structural heterogeneity across countries, we draw comparisons to Benigno et al. (2012) and Ready et al. (2017). Benigno et al. (2012) assume recursive utility and include a stochastic volatility component into a global productivity factor, but they do not have a long-run risk component. They also employ their model to study the effect of volatility and monetary policy shocks on the forward premium puzzle/anomaly. Our paper shares the mechanism of macroeconomic instability and precautionary saving in driving the currency risk premium with Ready et al. (2017). 
Combining recursive preferences with long-run risk and stochastic volatility processes is common in studies of international financial markets. Until recently, this has typically been done in an endowment economy framework. Bansal and Shaliastovich (2012) incorporate long-run risk and stochastic volatility in consumption growth and inflation. They focused on bond prices and not on the currency risk premium or the forward premium bias/anomaly. David et al. (2016) employ a similar structure to study average returns to capital in emerging markets. Kollmann (2016) models a stochastic volatility component in consumption growth to study international risk sharing. Colacito et al. (2018a) is a multi-country endowment model where consumption growth is a long-run risk and stochastic volatility process and is used to explain how the cross-section of currency risk premia emerge from cross-country variation in exposure to global endowment shocks. Consumption growth in Backus et al. (2020) is also a long-run risk and stochastic volatility process.

Our paper is part of an open economy modeling literature that features recursive utility in production models. In our model, productivity growth is subject to three shocks-a direct shock, a shock to the long-run risk component, and a shock to the stochastic volatility component. In contrast, productivity in Tretvoll (2018), Mumtaz and Theodoridis (2017), Berg and Mark (2019), and Kollmann (2019) is a cointegrated random walk. Productivity growth in Colacito et al. (2018b) has a long-run risk component but no stochastic volatility component, whereas in Benigno et al. (2012), productivity growth has a stochastic volatility component in a common global productivity component but no long-run risk component, and Gourio et al. (2013) have a disaster shock in productivity with recursive utility.

\section{The Model}

We present a two-country New Keynesian model under incomplete markets and refer to country 1 as the United States and country 2 as Japan. Labor is the only input into production, and prices are sticky in the sense of Calvo (1983). Since models in this class are well known and familiar to most readers, the text provides only a sketch of the model. We note that the model outlined in the text is nonstationary because the level of productivity is assumed to be a nonstationary variable. A numerical solution requires a stationary representation of the model, which we obtain by dividing the nonstationary variables by the one-period lag of the productivity level. Also, while we consider PCP, LCP, and DCP, except where indicated, the model is presented under LCP.

Early research, branching from the Mundell (1963)-Fleming (1962) tradition (e.g., Obstfeld and Rogoff (1995)), assumed both countries set export prices by PCP. Under PCP, the law-of-one price holds for every traded good. Questions about the appropriateness of this implication led to the development of models under LCP (Betts and Devereux (2000)). Recently, Gopinath et al. (2020) report evidence that the practice of DCP, with the U.S. dollar as the dominant currency, is widespread and pervasive. In our two-country setup, DCP results when the United States sets 
export prices by PCP and Japan sets its export prices by LCP.

Households have recursive utility and live in an incomplete markets environment. Each country issues a nominal bond denominated in its own currency and both bonds are traded internationally. The 'foreign' currency bond can serve as a hedge against changes in import prices.

\subsection{Households and Asset Markets}

Unless it is necessary to distinguish between countries $k \in\{1,2\}$, we will suppress the country subscript. Let $c_{t}$ be household consumption and $\ell_{t}$ be time worked. Households have recursive utility,

$$
V_{t}=(1-\beta)\left(\ln \left(c_{t}\right)-\eta \frac{\ell_{t}^{1+\chi}}{1+\chi}\right)-\frac{\beta}{\phi} \ln \left[\mathrm{E}_{t}\left(e^{-\phi V_{t+1}}\right)\right]
$$

where $\beta \in(0,1)$ is the subjective discount factor, $\eta>0, \chi>0$, and $\phi \in R$ are also parameters. $1 / \chi$ is the Frisch elasticity of labor supply. This particular logarithmic form of utility, which constrains the intertemporal elasticity of substitution to be 1, was introduced by Swanson (2019) and also employed by Berg and Mark (2019). Swanson (2019) shows that relative risk aversion is $R R A=\phi+\left(1+\frac{\eta}{\chi}\right)^{-1}$. The real stochastic discount factor (SDF) or equivalently the intertemporal marginal rate of substitution (IMRS) is

$$
M_{t+1}=\beta\left(\frac{c_{t}}{c_{t+1}}\right)\left(\frac{e^{-\phi V_{t+1}}}{\mathrm{E}_{t}\left(e^{\left.-\phi V_{t+1}\right)}\right.}\right)
$$

If $\pi_{t+1}$ is the inflation rate from $t$ to $t+1$, then the nominal SDF is $N_{t+1}=M_{t+1} e^{-\pi_{t+1}}$.

Each country issues a nominal, non-state contingent discount bond denominated in their own currency. The issue price is one unit of the currency and the payoff is $1+i_{t}$ units of the currency at $t+1$. These are the only internationally traded assets. Let $B_{k, j, t}>0$ be the number of bonds denominated in currency $j$ and held by agents of country $k(k, j \in\{1,2\})$. There are no short-sale constraints so if country $k$ agents have shorted the bond, then $B_{k, j, t}<0$. Let $b_{k, j, t}$ be the real value of bonds in terms of currency $j$.

To keep bond holdings stationary, we adopt the Schmitt-Grohe and Uribe (2003) method of imposing a small fee $\tau$ on residents on either their long or short positions on foreign currency denominated bonds. Let $S_{k, j, t}$ be the nominal exchange rate-the currency $k$ price of currency $j$, and $Q_{k, j, t}=\left(S_{k, j, t} P_{j, t}\right) / P_{k, t}$ be the real exchange rate, where $P_{k, t}$ is the price level of country $k$. The real cost to a country $k$ household for taking a position in the currency $j$ bond is $\Gamma\left(b_{k, j, t}\right)=$ $\frac{\tau}{2}\left(Q_{k, j, t} b_{k, j, t} / \sqrt{A_{k, t-1}}\right)^{2}$. In the steady state, for any $\tau>0$, households will want $b_{k, j}=b_{j, k}=0$. Because the level of productivity $\left(A_{k, t}\right)$ is nonstationary, we normalize the model by the oneperiod lagged productivity level $\left(A_{k, t-1}\right)$ to induce stationarity in the quantities. The term $A_{k, t-1}$ enters the bond tax formula in anticipation of the normalization.

Households own the firms only of their own country. Household resources consists of real firm 
profits $\Pi_{t}$, real labor income $w_{t} \ell_{t}$, and real bond payoffs. These resources are spent on consumption and a new bond portfolio. Let $r_{t}$ and $i_{t}$ be the real and nominal interest rates, respectively. The gross real bond return is $\left(1+r_{t-1}\right)=\left(1+i_{t-1}\right) e^{-\pi_{t}}$. The real budget constraint for a country $k$ household is

$c_{k, t}+b_{k, k, t}+Q_{k, j, t} b_{k, j, t}+\Gamma\left(b_{k, j, t}\right)=\left(1+r_{k, t-1}\right) b_{k, k, t-1}+\left(1+r_{j, t-1}\right) Q_{k, j, t} b_{k, j, t-1}+w_{k, t} \ell_{k, t}+\Pi_{k, t}$.

In equilibrium, we require zero net bonds outstanding. Hence, for $k, j \in\{1,2\}$ and $k \neq j$,

$$
0=b_{k, k, t}+b_{j, k, t}
$$

The equilibrium condition equation (4) says if $b_{2,1, t}>0$, Japan is long the U.S. dollar denominated bond but since Japan is a lender, the United States is a borrower and must be short the U.S. dollar denominated bond, $b_{1,1, t}<0$. This setup allows a type of carry trade when $b_{1,1, t}<0$ and $b_{1,2, t}>0$. The United States' short position in the U.S. dollar pays for the long position in the Japanese yen. Japan is the counter party who goes long the U.S. dollar and short the Japanese yen. International lending by Japan to the United States occurs if $b_{1,1, t}<0$ and $b_{1,2, t}<0$. Here, United States residents borrow both U.S. dollar and Japanese yen from Japan residents. The Euler equations associated with the bond choices for a country $k$ household are

$$
\begin{aligned}
& \text { Home Bond: } \frac{1}{\left(1+i_{k, t}\right)}=\mathrm{E}_{t}\left(M_{k, t+1} e^{-\pi_{k, t+1}}\right), \\
& \text { Foreign Bond: }\left(\frac{1}{1+i_{j, t}}\right)\left(1+\frac{\tau b_{k, j, t} Q_{k, j, t}}{A_{k, t-1}}\right)=\mathrm{E}_{t}\left(M_{k, t+1} e^{-\pi_{j, t+1}}\left(\frac{Q_{k, j, t+1}}{Q_{k, j, t}}\right)\right) .
\end{aligned}
$$

In each country, a continuum of firms, indexed by $f \in[0,1]$ each produce a differentiated product. Let $\lambda$ be the elasticity of substitution between varieties $f . c_{k, j, t}(f)$ are goods produced by firm $f$ in country $j$ and consumed in country $k$, and $p_{k, j, t}(f)$ is the price in currency $k$ (LCP) of that product. The index of imports $(k \neq j)$ or domestic demand $(k=j)$ and the associated price index are

$$
\begin{aligned}
c_{k, j, t} & =\left[\int_{0}^{1} c_{k, j, t}(f)^{\frac{\lambda-1}{\lambda}} d f\right]^{\frac{\lambda}{\lambda-1}}, \\
P_{k, j, t} & =\left[\int_{0}^{1} p_{k, j, t}(f)^{1-\lambda} d f\right]^{\frac{1}{1-\lambda}} .
\end{aligned}
$$


Aggregate demand of country $k$ and the associated price level are

$$
\begin{aligned}
c_{k, t} & =\left(d^{\frac{1}{\mu}} c_{k, k, t}^{\frac{\mu-1}{\mu}}+(1-d)^{\frac{1}{\mu}} c_{k, j, t}^{\frac{\mu-1}{\mu}}\right)^{\frac{\mu}{\mu-1}}, \\
P_{k, t} & =\left[d P_{k, k, t}^{1-\mu}+(1-d) P_{k, j, t}^{1-\mu}\right]^{\frac{1}{1-\mu}}
\end{aligned}
$$

where $\mu$ is the elasticity of substitution between the domestically produced and internationally produced goods.

\section{$2.2 \quad$ Firms}

Under LCP, firm $f \in[0,1]$ can distinguish between domestic and foreign shoppers and is able to charge them different prices. The production function for a firm in country $k$ where $k \in\{1,2\}$ is

$$
y_{k, t}(f)=A_{k, t} \ell_{k, t}(f)
$$

where $A_{k, t}$ is the productivity level. The firm's total costs are

$$
w_{k, t} \ell_{k, t}(f)
$$

Output is demand determined, $y_{k, t}(f)=c_{k, k, t}(f)+c_{j, k, t}(f)$, where $k \neq j$. Let $d$ be the degree of home bias. Domestic and foreign demands are, respectively,

$$
\begin{aligned}
& c_{k, k, t}(f)=d\left(\frac{p_{k, k, t}(f)}{P_{k, k, t}}\right)^{-\lambda}\left(\frac{P_{k, k, t}}{P_{k, t}}\right)^{-\mu} c_{k, t} \\
& c_{j, k, t}(f)=(1-d)\left(\frac{p_{j, k, t}(f)}{P_{j, k, t}}\right)^{-\lambda}\left(\frac{P_{j, k, t}}{P_{j, t}}\right)^{-\mu} c_{j, t} .
\end{aligned}
$$

It follows that labor employed by firm $f$ is

$$
\ell_{k, t}(f)=\frac{c_{k, k, t}(f)+c_{j, k, t}(f)}{A_{k, t}} .
$$

Prices are sticky in the sense of Calvo (1983). Each period, the firm is allowed to change its price with probability $1-\alpha$. LCP means firms in the United States set export prices in Japanese yen while firms in Japan set export prices in U.S. dollar. Price setting goes as follows. If a firm in country $k,(k, j \in\{1,2\}$ and $k \neq j)$, is chosen to reset prices, it adjusts both the currency $k$ price for the domestic market $\left(p_{k, k, t}(f)\right)$ and the currency $j$ price for exports $\left(p_{j, k, t}(f)\right)$. During the life of the contract, the price is indexed to the continuously compounded steady state inflation rate $\left(\bar{\pi}_{k}\right.$ for domestic or $\bar{\pi}_{j}$ for exports). These prices are set to maximize the expected present value of future profits with prices fixed at the optimal choices. Let $M_{k, t, t+h}=\prod_{z=0}^{h} M_{k, t+z}$ be 
the $h$-period real SDF. Formally, the problem for price resetting is to maximize

$$
\mathrm{E}_{t} \sum_{h=0}^{\infty}(\alpha)^{h} M_{k, t, t+h}\left[\frac{p_{k, k, t}(f) e^{h \bar{\pi}_{k}}}{P_{k, t+h}} c_{k, k, t+h}(f)+\frac{Q_{k, j, t+h} p_{j, k, t}(f) e^{h \bar{\pi}_{j}}}{P_{j, t+h}} c_{j, k, t+h}(f)-w_{i, t+h} \ell_{k, t+h}(f)\right],
$$

subject to the output demand equations $(12)$ and (13) and the labor demand equation (14).

Under PCP, firms in the United States set export prices in U.S. dollar while firms in Japan set export prices in Japanese yen, where $P_{k, j, t}$ is now denominated in country $j$ 's currency. The price level in equation 10 becomes $P_{k, t}=\left[d P_{k, k, t}^{1-\mu}+(1-d)\left(S_{k, j, t} P_{k, j, t}\right)^{1-\mu}\right]^{\frac{1}{1-\mu}}$. Domestic output demand $c_{k, k, t}(f)$ is again given by equation $(12)$, but foreign demand is

$$
c_{j, k, t}(f)=(1-d)\left(\frac{p_{j, k, t}(f)}{P_{j, k, t}}\right)^{-\lambda}\left(\frac{S_{j, k, t} P_{j, k, t}}{P_{j, t}}\right)^{-\mu} c_{j, t},
$$

and the firm's price setting problem is to choose prices to maximize

$$
E_{t} \sum_{h=0}^{\infty}(\alpha)^{h} M_{k, t, t+h}\left[\frac{p_{k, k, t}(f) e^{h \bar{\pi}_{k}}}{P_{k, t+h}} c_{k, k, t+h}(f)+\frac{p_{j, k, t}(f) e^{h \bar{\pi}_{k}}}{P_{k, t+h}} c_{j, k, t+h}(f)-w_{i, t+h} \ell_{k, t+h}(f)\right] .
$$

Under DCP, firms in the United States set export prices in U.S. dollars (they engage in PCP) while firms in Japan also set export prices in U.S. dollars (they engage in LCP).

\subsection{Monetary policy}

The monetary authorities set the interest rate according to a Taylor-type feedback rule that responds to deviations of inflation from its steady state level and the output gap. For country $k \in\{1,2\}$, we follow Swanson (2019) by setting the natural (log) level of output to be an infinitedimensional moving average of output,

$$
\ln \left(\bar{y}_{k, t}\right)=\rho_{y_{k}} \ln \left(\bar{y}_{k, t-1}\right)+\left(1-\rho_{y_{k}}\right) \ln \left(y_{k, t}\right) .
$$

The output gap is then the deviation between $\ln \left(y_{k, t}\right)$ and $\ln \left(\bar{y}_{k, t}\right)$. The monetary authorities set the short-term interest rate, with interest rate smoothing, according to

$$
i_{k, t}=\left(1-\delta_{k}\right) \bar{\imath}+\delta_{k} i_{k, t-1}+\left(1-\delta_{k}\right)\left[\xi_{k}\left(\pi_{k, t}-\bar{\pi}_{k}\right)+\zeta_{k}\left(\ln \left(y_{k, t}\right)-\ln \left(\bar{y}_{k, t}\right)\right)\right]+e_{k, t}
$$

where $\bar{\imath}$ is the steady state interest rate, $\bar{\pi}_{k}$ is the steady state inflation rate, and $e_{k, t} \stackrel{i i d}{\sim} N\left(0, \sigma_{e_{k}}^{2}\right)$. 


\subsection{Aggregation and equilibrium}

Aggregate demand for goods produced in country $k$ is given by equating firm $f$ 's supply to demand,

$$
A_{k, t} \ell_{k, t}(f)=d\left(\frac{P_{k, k, t}}{P_{k, t}}\right)^{-\mu}\left(\frac{p_{k, k, t}(f)}{P_{k, k, t}}\right)^{-\lambda} c_{k, t}+(1-d)\left(\frac{p_{j, k, t}(f)}{P_{j, k, t}}\right)^{-\lambda}\left(\frac{P_{j, k, t}}{P_{j, t}}\right)^{-\mu} c_{j, t},
$$

then integrating equation 20 to obtain,

$$
A_{k, t} \ell_{k, t}=c_{k, k, t} v_{k, k, t}^{p}+c_{j, k, t} v_{j, k, t}^{p}
$$

where $\ell_{k, t}=\int_{0}^{1} \ell_{k, t}(f) d f$ is total country $k$ employment, $c_{k, k, t}=d\left(\frac{P_{k, k, t}}{P_{k, t}}\right)^{-\mu} c_{k, t}=\left(\int_{0}^{1} c_{k, k, t}(f)^{\frac{\lambda-1}{\lambda}} d f\right)^{\frac{\lambda}{\lambda-1}}$

is aggregate domestic demand, and $c_{j, k, t}=(1-d)\left(\frac{P_{j, k, t}}{P_{j, t}}\right)^{-\mu} c_{j, t}=\left(\int_{0}^{1} c_{j, k, t}(f)^{\frac{\lambda-1}{\lambda}} d f\right)^{\frac{\lambda}{\lambda-1}}$ is aggregate export demand. In equation $21, v_{k, k, t}^{p} \equiv \int_{0}^{1}\left(\frac{p_{k, k, t}(f)}{P_{k, k, t}}\right)^{-\lambda} d f$ is a measure of price dispersion for goods in the domestic market and $v_{j, k, t}^{p} \equiv \int_{0}^{1}\left(\frac{p_{j, k, t}(f)}{P_{j, k, t}}\right)^{-\lambda} d f$ is import price dispersion in foreign country $j$. The recursive representation for the price dispersion terms, $v_{k, j, t}^{p}(k, j \in\{1,2\})$, is obtained by noting that a fraction $\alpha$ of these firms are stuck with last period's price, $p_{k, j, t-1}(f)$. Since there are a large number of firms charging what they charged last period, it will also be the case that $\int_{0}^{\alpha} p_{k, j, t-1}(f)^{-\lambda} d f=\alpha P_{k, j, t-1}^{-\lambda}$. The complementary measure of firms $(1-\alpha)$ are able to reset the prices for exports and the domestic market. They all reset to the same price, $p_{k, j, t}^{*}$. The result is the recursive representation,

$$
v_{k, j, t}^{p}=(1-\alpha)\left(\frac{p_{k, j, t}^{*}}{P_{k, j, t}}\right)^{-\lambda}+\alpha\left(\frac{P_{k, j, t-1}}{P_{k, j, t}}\right)^{-\lambda} v_{k, j, t-1}^{p} e^{-\lambda \bar{\pi}_{k}}
$$

\section{Long-Run Risk and Stochastic Volatility Process for Produc- tivity Growth}

We specify productivity growth to be a long-run risk and stochastic volatility process. The productivity model for the United States and Japan is estimated from Japan and United States total factor productivity using Bayesian methods.

\subsection{The Process}

Let $a_{t}=\ln \left(A_{t}\right)$ be $\log$ productivity. Let $x_{t}$ be the long-run risk component and $\sigma_{t}$ be the stochastic volatility component. Suppressing notation to differentiate parameter values across 
countries, log productivity growth is governed by

$$
\begin{aligned}
\Delta a_{t} & =\mu_{g}+x_{t-1}+e^{\theta} \sigma_{t-1} \epsilon_{t}, \\
x_{t} & =\rho_{x} x_{t-1}+\sigma_{t-1} u_{t}, \\
\ln \left(\sigma_{t}\right) & =\mu_{\sigma}\left(1-\rho_{\sigma}\right)+\rho_{\sigma} \ln \left(\sigma_{t-1}\right)+e^{\eta} v_{t},
\end{aligned}
$$

where $\epsilon_{t} \stackrel{\text { nid }}{\sim}(0,1), u_{t} \stackrel{\text { nid }}{\sim}(0,1)$, and $v_{t} \stackrel{\text { nid }}{\sim}(0,1)$.

Typically, long-run risk in international macroeconomics and finance is used to model consumption growth in endowment models (Bansal and Yaron. (2004), Bansal and Shaliastovich (2012), Backus et al. (2020), and Colacito et al. (2018a)). In (closed economy) macro models, technology shocks with stochastic volatility is more extensively studied (see the review article by Fernández-Villeverde and Guerrón-Quintana (2020)). Our specification for the stochastic volatility process follows Fernández-Villeverde and Guerrón-Quintana (2020) to keep $\sigma_{t}$ positive.

Heterogeneity in productivity enters through cross-country differences in parameter values. Using quarterly GDP, investment, and employment data from Datastream and FRED, and converted to constant U.S. dollar, we construct the capital stock by the perpetual inventory method. From this, we construct quarterly total factor productivity (TFP). Figure 1 shows log TFP for Japan and the United States. The time period for the United States is 1973Q1 to 2014Q4 and for Japan is 1980Q1 to 2014Q4. As can be seen, Japan experienced high growth in the 1980s then slowed thereafter.

Figure 1: Log Productivity for the United States (USA) and Japan (JPN)

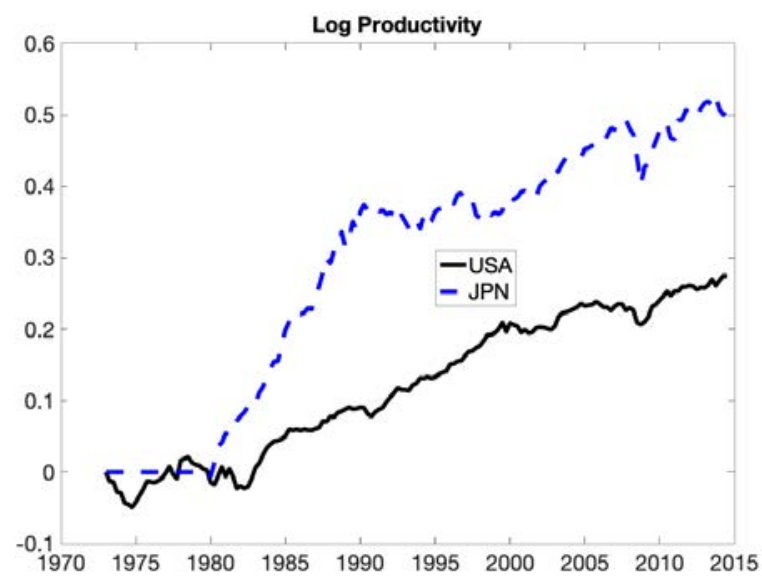

We estimate the productivity growth process in equations (23)-(25) separately for the United States and Japan ${ }^{2}$ We employ the posterior means from the Bayesian estimation as the parameter

\footnotetext{
${ }^{2}$ In the model simulations, United States and Japanese productivity will be tied together by a cointegrating restriction.
} 
values in the long-run risk and stochastic volatility process for productivity growth. The posterior means are shown in Table 1 . The volatility of the process components $\left(\Delta a_{t}, x_{t}, \sigma_{t}\right)$ implied by the estimates are shown in Table 2 .

Table 1: Posterior Means-Long-Run Risk and Stochastic Volatility Processes

\begin{tabular}{lrrrrrr}
\hline \hline & $\mu_{g}$ & $\theta$ & $\rho_{x}$ & $\rho_{\sigma}$ & $\eta$ & $\mu_{\sigma}$ \\
\hline United States & 0.002 & 0.870 & 0.740 & 0.839 & -1.267 & -6.042 \\
Japan & 0.004 & 1.059 & 0.752 & 0.841 & -1.758 & -5.675 \\
\hline \hline
\end{tabular}

Table 2: Productivity Growth and Component Volatility

\begin{tabular}{lr|rrr}
\hline \hline & $\underline{\text { Data }}$ & \multicolumn{3}{|c}{ Simulated } \\
& $\sigma\left(\Delta a_{t}\right)$ & $\sigma\left(\Delta a_{t}\right)$ & $\sigma\left(x_{t}\right)$ & $\sigma\left(\sigma_{t}\right)$ \\
\hline United States & 2.605 & 3.449 & 1.914 & 0.625 \\
Japan & 4.392 & 5.179 & 2.304 & 0.494 \\
\hline \hline
\end{tabular}

Note: $\sigma(\bullet)$ is the volatility or standard deviation of the variable stated as percent per annum.

As can be seen, the estimated long-run risk and stochastic volatility model slightly overstates the volatility of $\Delta a_{t}$. Both in the data and implied by the estimated processes, productivity growth is a good deal more volatile in Japan than in the United States. The stochastic volatility component in the United States is more volatile than in Japan, but Japan's productivity growth and it's long-run risk component are considerably more volatile than for the United States.

Figure 2 plots productivity growth and log levels from the data as well as a realized simulation. As can be seen, the model does a reasonable job of capturing major features of the productivity data. 
Figure 2: Data and Realized Simulation
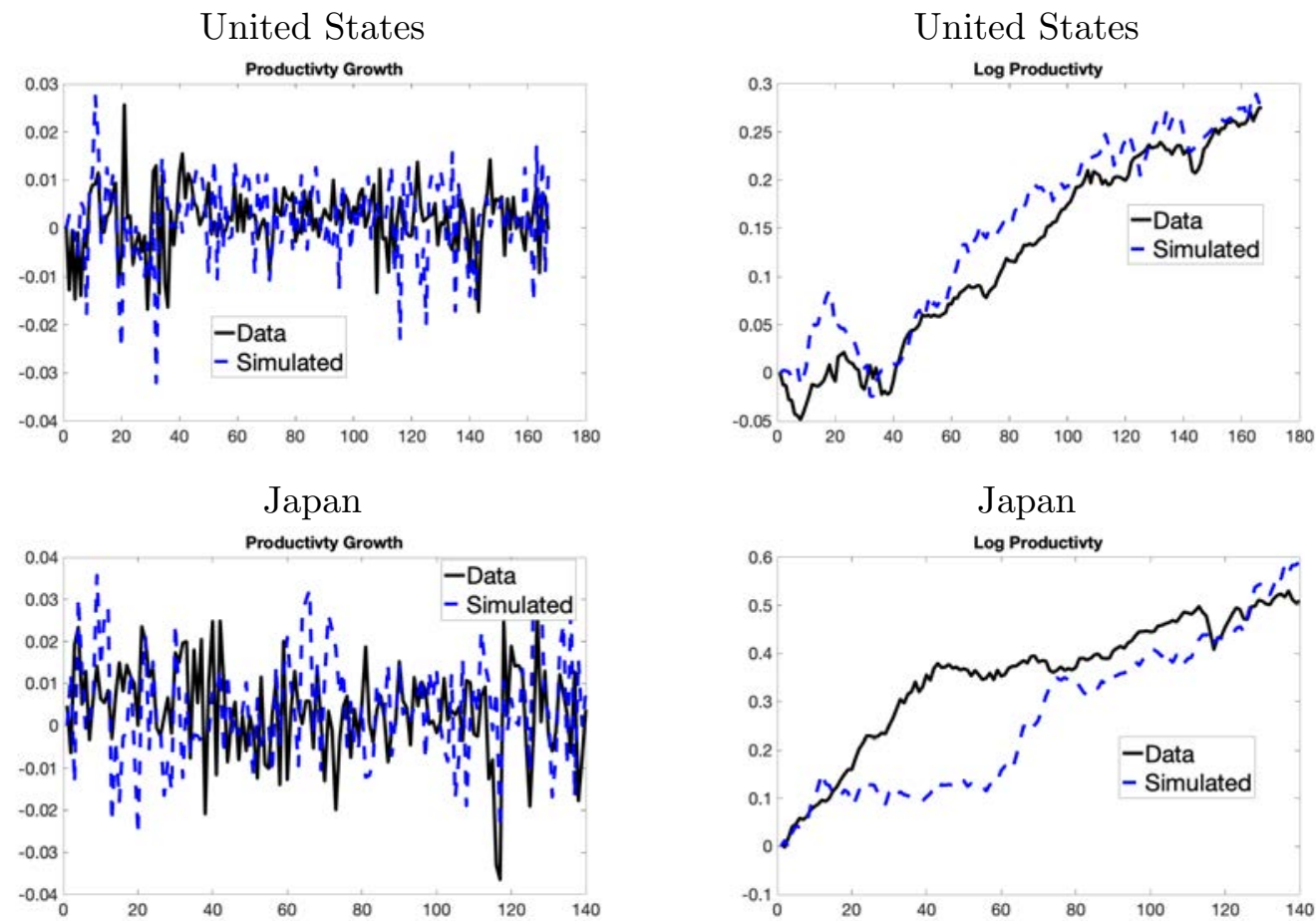

Two notable features of the productivity data seen in Figure 1 and Figure 2 (data, not simulated) are that log TFP of the two countries have positive drift and they do not appear to be cointegrated. To solve the model, however, we modify the specification such that the United States (country 1) log productivity and Japan (country 2) log productivity are driftless and they are cointegrated, but not strongly so. The processes are modified as follows,

$$
\begin{aligned}
& \Delta a_{1, t}=x_{1, t-1}+e^{\theta_{1}} \sigma_{1, t-1} \epsilon_{1, t}+\psi\left(a_{1, t-1}-a_{2, t-1}\right) \\
& \Delta a_{2, t}=x_{2, t-1}+e^{\theta_{2}} \sigma_{2, t-1} \epsilon_{2, t}+\psi\left(a_{2, t-1}-a_{1, t-1}\right)
\end{aligned}
$$

with $\psi=0.0005$.

\section{Measures of International and Currency Risk}

We use the DSGE model primarily to further our understanding of the forward premium bias/anomaly, the currency risk premium, and the carry trade excess return. But, there are associated data features-the Backus and Smith (1993) puzzle and the consumption correlation puzzle of Backus et al. (1992) -that are complementary measures of international risk sharing that we also inves- 
tigate with the model. Because these data features are well-known in the literature, we will be brief in their presentation.

Forward Premium Bias/Anomaly. This has been well known in international economics ever since Bilson (1981) and Fama (1984), and is the primary focus of Backus et al. (2020). Uncovered interest rate parity predicts that a regression of the future nominal exchange rate depreciation $\left(\Delta \ln \left(S_{1,2, t+1)}\right)\right.$ on the interest rate differential $\left(i_{1, t}-i_{2, t}\right)$ has a constant of zero and a slope coefficient of one. We refer to this as the Fama (1984) regression and the slope coefficient in this regression as $\beta_{F a m a}$. Researchers typically estimate the slope coefficient to be positive but less than one. This is known to as the forward premium bias. For many currency pairs, and data samples, the estimated slope coefficient is negative. This is known as the forward premium anomaly (Froot and Thaler (1990). Here, the interest rate differential predicts the future exchange rate depreciation but with the 'wrong' sign. Hodrick and Srivastava (1984) argue that the period from the breakdown of the fixed exchange rate system under Bretton-Woods until formal ratification of the Rambouillet agreement should be omitted. Hence, our sample runs from 1976Q1-2020Q1. The countries are the G-10 plus Australia.

Individual regressions of the future nominal exchange rate depreciation on the nominal interest rate differential with the United States as country 1 gives an average value of $\beta_{\text {Fama }}=-0.825$. In the regression for the United States and Japan, we obtain $\beta_{\text {Fama }}=-1.718$.

Currency Risk Premium. We define this to be the expected excess return from shorting the Japanese yen and going long the U.S. dollar,

$$
r p_{1,2, t}=\mathrm{E}_{t}\left(i_{1, t}-i_{2, t}-\Delta \ln \left(S_{1,2, t+1}\right)\right) .
$$

This is the expected currency excess return to be paid by the United States, which can be positive or negative. The mean value in the data from shorting the G-10 currencies (plus Australia) and going long the U.S. dollar is -0.626 percent per annum. The average currency risk premium from shorting the Japanese yen and going long the U.S. dollar is 0.238 percent per annum.

Carry Trade Excess Return. This is the excess return from shorting the low interest rate currency and going long the high interest rate currency. This trading strategy has proven to be profitable over time. While it is related to the forward premium bias, this is a different phenomenon (Hassan and Mano (2019)). The average carry trade excess return between the United States and G-10 countries plus Australia is 2.937 percent per annum. The carry between the United States and Japan is 2.861 percent per annum. $3^{3}$ See Lustig and Verdelhan (2007), Lustig et al. (2011), Menkhoff et al. (2012), Berg and Mark (2017) and Berg and Mark (2018) for research on the 'pricing' of and empirical determination of the carry trade excess return.

\footnotetext{
${ }^{3}$ Even higher profits can be generated with portfolios of carry trades, but in this paper we look only at the bilateral carry.
} 
Backus-Smith. Backus and Smith (1993), working with a complete markets two-country model under expected utility, provided perhaps, the first treatment of the SDF approach to the exchange rate. The key prediction from their paper is that the real exchange rate depreciation is exactly proportional to the difference in consumption growth,

$$
\Delta \ln \left(Q_{1,2, t}\right)=\gamma\left(\Delta \ln \left(c_{1, t}\right)-\Delta \ln \left(c_{2, t}\right)\right)
$$

where $\gamma>0$ is the coefficient of relative risk aversion. The puzzle is, in the data, the difference in consumption growth explains almost none of the real exchange rate depreciation. Adding a constant and a set of seasonal dummies to equation (28), we run the quarterly regression $\Delta \ln \left(Q_{1,2, t}\right)=c+\gamma\left(\Delta \ln c_{1, t}-\Delta \ln c_{2, t}\right)+X_{t} \delta^{\prime}+\epsilon_{t}$ where $X_{t}$ is a set of seasonal dummies, the United States is country 1, and each of the other G-10 countries plus Australia take turns being country 2. This gives an average point estimate of $\gamma=0.300$ and an average $R^{2}=0.037$. The single regression between the United States and Japan gives $\gamma=0.221$ and an $R^{2}=0.025$.

International Risk Sharing. Brandt et al. (2006) assume complete markets and begin with the SDF approach to the exchange rate, $\Delta \ln \left(Q_{1,2, t}\right)=\ln \left(M_{2, t}\right)-\ln \left(M_{1, t}\right)$, where $M$ is the real SDF. Passing the variance operator through on both sides shows that to explain the observed variance of exchange rates, risks must be shared extensively across countries (log SDFs highly correlated). They propose the following index of international risk sharing,

$$
\mathcal{R}_{s}=1-\frac{\operatorname{Var}\left(\ln \left(M_{2, t+1}\right)-\ln \left(M_{1, t+1}\right)\right)}{\operatorname{Var}\left(\ln \left(M_{2, t+1}\right)\right)+\operatorname{Var}\left(\ln \left(M_{1, t+1}\right)\right)}
$$

If the index is one, then all risk is being shared. If $\mathcal{R}_{s}$ is zero, then no risk is shared. Brandt et al. (2006)'s calculations of the risk-sharing index using consumption data and assuming constant relative risk aversion utility ranged from 0.17 to 0.42 , which they conclude is much too low to explain exchange rate volatility. Our calculations in the next section use the recursive utility function in equation (1).

Output and Consumption Correlations. Backus et al. (1992) showed in a complete markets real business cycle model, when risks are shared internationally, that the cross-country correlation of consumption is higher than the cross-country correlation of output. The puzzle has been, in the data, consumption correlations are lower than output correlations. Using the United States as the base country, the average correlation of output growth against the G-10 countries plus Australia is 0.260 and the average correlation of consumption growth is 0.300 . Using Japan as the base country, the average output growth correlation is 0.037 and the average consumption growth correlation is 0.300 . In our data, the puzzle is not present, however, both output and consumption growth correlations are quite low 4

\footnotetext{
${ }^{4}$ One point of departure from Backus et al. (1992) and others, is that the literature typically computes correlations
} 


\section{Model Simulation}

We use the following parameter values throughout. Home bias is $d=0.85$ and price stickiness is $\alpha=0.8$, which implies an average contract duration of three quarters. For the utility function, $(\beta, \eta, \chi, \phi)=(0.993,0.545,3,40)$. High degrees of risk aversion are typically needed to explain asset returns data. The parameters governing elasticities are $\lambda=10$ and $\mu=1.5$. Degree of interest rate smoothing is $\delta_{1}=\delta_{2}=0.7$. Interest rates are less variable in Japan than in the United States. Standard deviations of monetary policy shocks are $\sigma_{e_{1}}=0.0044$ for the United States and $\sigma_{e_{2}}=0.0034$ for Japan, which are drawn from the author's estimates of monetary policy rules (not reported). The cointegrating coefficient for productivity is $\psi=0.0005$ and the international asset participation cost is $\tau=0.001$. The model is solved numerically with Dynare 4.5.7 using a third-order approximation around the nonstochastic steady state with pruning. Implied moments are from a model simulation of 50,000 periods.

\section{$5.1 \quad$ Symmetry}

Opportunities for international risk sharing are limited when the difference between countries is small. Hence, we begin by benchmarking the model when monetary policy and productivity growth are symmetric across both countries. For the interest rate response rule for both countries, the inflation response coefficient is $\xi=1.5$ and the output gap response coefficient is $\zeta=0.5$. The productivity parameters for both countries are set to estimated values for the United States. We consider the three alternative export pricing conventions. Under PCP and LCP, the model is completely symmetric. Under DCP, the only country heterogeneity is in export pricing. Here and in the sections that follow, we continue to refer to country 1 as the United States and country 2 as Japan. Table 3 reports the results under symmetry.

of Hodrick and Prescott 1997) detrended consumption and output, whereas we use the first-difference filter to induce stationarity in consumption and output. 
Table 3: International Moments under Symmetric Monetary Policy and Productivity Growth

\begin{tabular}{llrrr}
\hline \hline & & PCP & LCP & DCP \\
\hline 1. & $\beta_{\text {Fama }}$ & 0.829 & 0.755 & 0.768 \\
2. & $\mu$ (risk premium) & -0.012 & -0.011 & 0.050 \\
3. & $\mu$ (carry) & 0.049 & 0.053 & 0.081 \\
4. & Backus-Smith slope & 0.469 & 0.685 & 0.599 \\
5. & Backus-Smith $R^{2}$ & 0.442 & 0.664 & 0.573 \\
6. & $\mathcal{R}_{s}$ & 0.219 & 0.213 & 0.202 \\
7. & $\rho\left(\Delta y_{1}, \Delta y_{2}\right)$ & -0.164 & 0.237 & 0.036 \\
8. & $\rho\left(\Delta c_{1}, \Delta c_{2}\right)$ & 0.129 & -0.114 & -0.008 \\
9. & $\rho\left(M_{1}, M_{2}\right)$ & 0.245 & 0.239 & 0.226 \\
\hline \hline
\end{tabular}

Note: Monetary policy settings are $\xi=1.5$ and $\zeta=0.5$ for both countries 1 and 2. The long-run risk and stochastic volatility process for productivity growth are calibrated to estimated parameters for the United States for both countries 1 and 2. Statistics are computed from a simulation of the model for 50,000 periods. The currency risk premium is from shorting the Japanese yen and going long the U.S. dollar. The currency risk premium and the carry trade excess return are stated in percent per annum. $\mu(\bullet)$ denotes a mean value and $\rho(\bullet)$ denotes a correlation value.

This ultra-symmetric world generates a slight forward premium bias $\left(0<\beta_{\text {Fama }}<1\right)$ and tiny values for the mean currency risk premium and the mean carry trade excess return (lines 2 and 3 ). The amount of international risk sharing (line 6) is quite low, which is expected when countries are so similar. The magnitude of the $\mathcal{R}_{s}$ index is about the same size as the correlation between the real SDFs. The model qualitatively explains the consumption correlation puzzle under LCP and DCP.

However, the model generates too much correlation between relative consumption growth and the real exchange rate depreciation. The slope in the Backus-Smith regression is relatively large and positive, and the $R^{2}$ from the model is also too high, as compared to the data.

\subsection{Monetary Policy Risks}

Here, we examine monetary policy induced risk by introducing policy heterogeneity while keeping the productivity parameters in both countries equal to the estimates for the United States. Export pricing is DCP ${ }^{5}$ The results are shown in Table 4 . Column 1 (monetary policy symmetry) is reproduced from Table 3 for ease of comparison.

\footnotetext{
${ }^{5}$ The results for LCP and PCP are nearly identical and not reported.
} 
Table 4: International Moments under Asymmetric Monetary Policy, Symmetric Productivity Growth, and DCP

\begin{tabular}{|c|c|c|c|c|c|}
\hline & $(1)$ & & $(2)$ & $(3)$ & $(4)$ \\
\hline \multicolumn{6}{|c|}{ A. Monetary Policy } \\
\hline 1. & 1.5 & $\xi_{1}$ & 1.5 & 1.5 & 1.5 \\
\hline 2. & 0.5 & $\zeta_{1}$ & 0.5 & 0.5 & 0.5 \\
\hline 3. & 1.5 & $\xi_{2}$ & 1.5 & 1.35 & 1.35 \\
\hline 4. & 0.5 & $\zeta_{2}$ & 1.17 & 0.5 & 1.17 \\
\hline \multicolumn{6}{|c|}{ B. Implied International Moments } \\
\hline 5. & 0.768 & $\beta_{\text {Fama }}$ & 0.651 & 0.552 & 0.803 \\
\hline 6. & 0.050 & $\mu($ risk premium $)$ & -0.404 & 0.112 & -0.373 \\
\hline 7. & 0.081 & $\mu($ carry $)$ & 0.168 & 0.100 & 0.097 \\
\hline 8. & 0.599 & Backus-Smith slope & 0.572 & 0.599 & 0.573 \\
\hline 9. & 0.573 & Backus-Smith $R^{2}$ & 0.514 & 0.578 & 0.516 \\
\hline 10. & 0.202 & $\mathcal{R}_{s}$ & 0.201 & 0.209 & 0.208 \\
\hline 11. & 0.036 & $\rho\left(\Delta y_{1}, \Delta y_{2}\right)$ & 0.025 & 0.039 & 0.026 \\
\hline 12. & -0.008 & $\rho\left(\Delta c_{1}, \Delta c_{2}\right)$ & -0.026 & -0.004 & -0.024 \\
\hline 13. & 0.226 & $\rho\left(M_{1}, M_{2}\right)$ & 0.225 & 0.234 & 0.233 \\
\hline 14. & 0.408 & $\rho\left(\Delta c_{1}, \pi_{1}\right)$ & 0.411 & 0.407 & 0.410 \\
\hline 15. & 0.538 & $\rho\left(\Delta c_{2}, \pi_{2}\right)$ & 0.298 & 0.531 & 0.286 \\
\hline 16. & 4.710 & $\sigma\left(\Delta y_{1}\right)$ & 4.713 & 4.708 & 4.712 \\
\hline 17. & 4.661 & $\sigma\left(\Delta y_{2}\right)$ & 3.436 & 4.766 & 3.464 \\
\hline
\end{tabular}

Note: The long-run risk and stochastic volatility process for productivity growth are calibrated to estimated parameters for the United States for both countries 1 and 2. Statistics are computed from a simulation of the model for 50,000 periods. The currency risk premium is from shorting the Japanese yen and going long the U.S. dollar. The currency risk premium and the carry trade excess return are stated in percent per annum. $\mu(\bullet)$ denotes a mean value, $\rho(\bullet)$ denotes a correlation value, and $\sigma(\bullet)$ denotes a standard deviation value.

We discuss these results in relation to Backus et al. (2020), who study monetary policy induced international risk. They work with a two-country complete markets endowment economy model. In their model, consumption growth is exogenous and follows a long-run risk and stochastic volatility process. Their interest rates are governed by Taylor-type feedback rules (but without interest rate smoothing) which generates endogenous inflation. Two central predictions from their paper are, the currency risk premium from long the U.S. dollar and short the Japanese yen is (a) decreasing in $\zeta_{2}-\zeta_{1}$, if $\zeta_{2}-\zeta_{1}>0$, and (b) is decreasing in $\xi_{1}-\xi_{2}$ if $\xi_{1}-\xi_{2}>0$.

In column 2 of Table 4, Japan's monetary policy is relatively more procyclical $\left(\zeta_{2}-\zeta_{1}>0\right)$. This shows that Backus et al. (2020)'s prediction (a) carries over to a production setting under incomplete markets. The mean currency risk premium from long the U.S. dollar drops to -0.404 from 0.050 under symmetric monetary policy. The forward premium bias is also a bit stronger ( $\beta_{\text {Fama }}$ declines). The mechanism articulated in Backus et al. (2020) is increasing $\zeta_{2}$ lowers 
the correlation between consumption growth and inflation, which means increasing inflation risk. Since the nominal SDF is related to the real SDF by $N_{t+1}=M_{t+1} e^{-\pi_{t+1}}$, and with the real SDF being exogenous in their framework, lowering the correlation between consumption growth and inflation necessarily lowers the variance of the nominal SDF $\left(\operatorname{Var}_{t}\left(\ln \left(N_{t+1}\right)\right)\right)$. Under complete markets and log normality of the SDF (Backus et al. (2001)), the currency risk premium is determined by the difference in the variances of the nominal SDFs,

$$
\mathrm{E}_{t}\left(i_{1, t}-i_{2, t}-\Delta \ln \left(S_{1,2, t+1}\right)\right)=\frac{\operatorname{Var}_{t}\left(\ln \left(N_{2, t+1}\right)\right)-\operatorname{Var}_{t}\left(\ln \left(N_{1, t+1}\right)\right)}{2} .
$$

Hence, depressing $\operatorname{Var}_{t}\left(\ln \left(N_{2, t+1}\right)\right)$ lowers the currency excess return from short the Japanese yen and long the U.S. dollar. Although we have incomplete markets, our results are consistent with the complete markets intuition of Backus et al. (2020). $\rho\left(\Delta c_{2}, \pi_{2}\right)$ declines from 0.538 to 0.298. But, the inflation risks channel is not the only one operating in our model. We return to this point below.

In column 3, we make Japan's monetary policy relatively more accommodating to inflation $\left(\xi_{1}-\xi_{2}>0\right)$. This experiment addresses Backus et al. (2020)'s prediction (b), which in comparing to column 1, says we should see a decline in the long U.S. dollar short Japanese yen currency excess return. Instead, we see the mean currency risk premium increase from 0.050 to 0.112 . In Backus et al. (2020), changes in the monetary policy rule affect inflation dynamics and, because consumption growth is exogenous, will necessarily affect the correlation between inflation and consumption growth. In our model, this is not the case. The inflation risk, as measured by the correlation between $\Delta c_{2}$ and $\pi_{2}$ is essentially unchanged between columns 1 and 3 . In fact, between columns 1 and 3, there are very little differences in correlations of consumption growth, output growth, and real SDFs. However, inflation accommodation by Japan in our model is destabilizing. Lowering $\xi_{2}$ increases the volatility of Japan inflation, consumption growth, and output growth 6 This leads to an increased desire for precautionary saving by people in Japan. To go long in Japanese yen denominated bonds (increase $b_{2,2}$ ), people in the United States must be induced to short Japanese yen denominated bonds (decrease $b_{1,2}$ ). A higher excess return on the U.S. dollar incentivizes people to do this. People in the United States can use the proceeds from shorting the Japanese yen denominated bonds to go long the U.S. dollar denominated bond. Note also that a bit more risk is now being shared internationally $\left(\mathcal{R}_{s}\right.$ increases from 0.202 to 0.209). The mechanism by which monetary policy is destabilizing is absent in Backus et al. (2020) due to the exogeneity of consumption.

Circling back to the experiment in column 2, we see in addition to the added inflation risk channel discussed above, making Japan's monetary policy relatively more procyclical is also stabilizing (line 17). This stabilizing effect reduces the desire for precautionary saving in Japan relative to the United States, and reinforces the currency excess return being paid by Japan.

\footnotetext{
${ }^{6}\left(\sigma\left(\pi_{2}\right), \sigma\left(\Delta c_{2}\right)\right.$, and $\left.\sigma\left(\Delta y_{2}\right)\right)$ increase from $(2.484,4.8068$, and 4.6606$)$ to $(2.7785,4.9168$, and 4.7657$)$.
} 
In column 4, we combine the relatively more procyclical and the accommodation to inflation aspects of monetary policy for Japan. Not surprisingly, some of the effects from the procyclical aspect are undone by the inflationary accommodation.

In terms of the complementary risk-sharing measures, introducing monetary policy heterogeneity, to the extent that we have considered, have modest effects on the Backus-Smith puzzle, the consumption correlation puzzle, and the amount of international risk sharing:7

\subsection{Productivity Risks}

Here, we show that empirically based heterogeneity in productivity growth is potentially a more important source of currency risk than are differences in monetary policy. Monetary policy is again symmetric with $\xi=1.5$ and $\zeta=0.5$ in both countries. Country 1 productivity growth parameters are set to the estimated values for the United States and country 2 are set to the estimated values for Japan. Results under PCP, LCP, and DCP are presented in Table 5.

Table 5: International Moments under Symmetric Monetary Policy and Asymmetric Productivity Growth

\begin{tabular}{llrrr}
\hline \hline & & PCP & LCP & DCP \\
\hline 1. & $\beta_{\text {Fama }}$ & -1.079 & -1.024 & -1.371 \\
2. & $\mu$ (risk premium) & 1.358 & 1.433 & 1.524 \\
3. & $\mu$ (carry) & 1.282 & 1.336 & 1.459 \\
4. & Backus-Smith slope & 0.366 & 0.587 & 0.484 \\
5. & Backus-Smith $R^{2}$ & 0.331 & 0.565 & 0.436 \\
6. & $\mathcal{R}_{s}$ & 0.262 & 0.256 & 0.244 \\
7. & $\rho\left(\Delta y_{1}, \Delta y_{2}\right)$ & -0.084 & 0.227 & 0.064 \\
8. & $\rho\left(\Delta c_{1}, \Delta c_{2}\right)$ & 0.127 & -0.071 & 0.037 \\
9. & $\rho\left(M_{1}, M_{2}\right)$ & 0.278 & 0.272 & 0.261 \\
10. & $\rho\left(\Delta c_{1}, \pi_{1}\right)$ & 0.479 & 0.412 & 0.398 \\
11. & $\rho\left(\Delta c_{2}, \pi_{2}\right)$ & 0.336 & 0.294 & 0.379 \\
12. & $\sigma\left(\Delta y_{1}\right)$ & 5.204 & 4.261 & 4.759 \\
13. & $\sigma\left(\Delta y_{2}\right)$ & 5.473 & 4.953 & 5.226 \\
\hline \hline
\end{tabular}

Note: Monetary policy settings are $\xi=1.5$ and $\zeta=0.5$ for both countries 1 and 2. Productivity growth parameters for country 1 are set to United States estimates and country 2 parameters are set to Japan estimates. Statistics are computed from a simulation of the model for 50,000 periods. The currency risk premium is from shorting the Japanese yen and going long the U.S. dollar. The currency risk premium and the carry trade excess return are stated in percent per annum. $\mu(\bullet)$ denotes a mean value, $\rho(\bullet)$ denotes a correlation value, and $\sigma(\bullet)$ denotes a standard deviation value.

Recall that these settings make Japan the more volatile country, with higher productivity and output growth volatility. This cross-country heterogeneity in productivity growth is seen to

\footnotetext{
${ }^{7}$ The results of this section are not specific to DCP. They also hold under LCP and PCP.
} 
create a good deal more international currency risk than monetary policy heterogeneity, at least to the extent that we explored in the previous subsection. Even under symmetric Taylor-rule monetary policy, the heterogeneous productivity model produces the forward premium anomaly (i.e., $\beta_{\text {Fama }}<0$ ).

Under DCP, the model generates an mean currency risk premium from shorting the Japanese yen and going long the U.S. dollar of 1.524 percent per annum, and a mean carry trade excess return of 1.459 percent per annum. The additional cross-country heterogeneity due to DCP marginally adds to currency risk beyond that generated under LCP and PCP.

The complementary risk-sharing measures are not very different from before. The model continues to explain the consumption correlation puzzle under DCP and LCP. Output correlations are near zero. Slightly more international risk is being shared. The slope and $R^{2}$ in the BackusSmith puzzle regression are smaller in magnitude, but are still substantially larger than what is estimated in the data. Currency risk is again driven by higher volatility of the Japanese economy and higher desired precautionary saving by people in Japan relative to the United States.

\subsection{Combined Monetary Policy and Productivity Risks under DCP}

In Table 6, we show results from variations in monetary policy, as in Subsection 5.2, combined with estimated productivity growth heterogeneity, as in Subsection 5.3. Column 1 in Table 6 is taken from Table 5 under symmetric monetary policy and DCP for ease of comparison. In column 2, Japan's monetary policy is relatively more procyclical. This is stabilizing the Japanese economy. Volatility of output growth in Japan decreases, and is lower than that of the United States. This leads to substantial reductions in the mean currency risk premium and the mean carry trade excess return, but does not change the signs. We do not get a reversal of the sign of the mean currency risk premium, in part, because there is more inflationary risk in the United States (line 14), which contributes towards a mean currency risk premium that is paid by the United States. Comparing columns 1 and 2, the relatively more procyclical Japan monetary policy has a stabilizing effect (lowering $\sigma\left(\Delta y_{2}\right)$ ) and reduces the mean currency risk premium paid by the United States. However, in column $2, \sigma\left(\Delta y_{2}\right)<\sigma\left(\Delta y_{1}\right)$, but the United States pays the currency risk premium. While relative output growth volatility evidently is not a sufficient statistic for determining who pays the premium, these results lead us to conjecture that the mean currency risk premium is decreasing in $\sigma\left(\Delta y_{1}\right)-\sigma\left(\Delta y_{2}\right)$. 
Table 6: International Moments under Asymmetric Monetary Policy and Productivity Growth and DCP

\begin{tabular}{|c|c|c|c|c|c|c|}
\hline & $(1)$ & & $(2)$ & $(3)$ & $(4)$ & $(5)$ \\
\hline \multicolumn{7}{|c|}{ A. Monetary Policy } \\
\hline 1. & 1.5 & $\xi_{1}$ & 1.5 & 1.5 & 1.5 & 1.5 \\
\hline 2. & 0.5 & $\zeta_{1}$ & 0.5 & 0.5 & 0.5 & 0.5 \\
\hline 3. & 1.5 & $\xi_{2}$ & 1.5 & 1.35 & 1.35 & 2.06 \\
\hline 4. & 0.5 & $\zeta_{2}$ & 1.17 & 0.5 & 1.17 & 0.43 \\
\hline \multicolumn{7}{|c|}{ B. Implied International Moments } \\
\hline 5. & -1.371 & $\beta_{\text {Fama }}$ & 0.725 & -4.613 & -0.075 & 0.611 \\
\hline 6. & 1.524 & $\mu($ risk premium $)$ & 0.470 & 1.679 & 0.546 & 1.481 \\
\hline 7. & 1.459 & $\mu($ carry $)$ & 0.223 & 1.720 & 0.458 & 0.953 \\
\hline 8. & 0.484 & Backus-Smith slope & 0.473 & 0.477 & 0.474 & 0.497 \\
\hline 9. & 0.436 & Backus-Smith $R^{2}$ & 0.379 & 0.434 & 0.378 & 0.434 \\
\hline 10. & 0.244 & $\mathcal{R}_{s}$ & 0.258 & 0.259 & 0.251 & 0.260 \\
\hline 11. & 0.064 & $\rho\left(\Delta y_{1}, \Delta y_{2}\right)$ & 0.039 & 0.067 & 0.039 & 0.054 \\
\hline 12. & 0.037 & $\rho\left(\Delta c_{1}, \Delta c_{2}\right)$ & 0.019 & 0.039 & 0.023 & 0.035 \\
\hline 13. & 0.261 & $\rho\left(M_{1}, M_{2}\right)$ & -0.071 & 0.315 & -0.178 & 0.439 \\
\hline 14. & 0.398 & $\rho\left(\Delta c_{1}, \pi_{1}\right)$ & 0.241 & 0.243 & 0.235 & 0.243 \\
\hline 15. & 0.379 & $\rho\left(\Delta c_{2}, \pi_{2}\right)$ & 0.403 & 0.397 & 0.403 & 0.399 \\
\hline 16. & 4.759 & $\sigma\left(\Delta y_{1}\right)$ & 4.757 & 4.759 & 4.758 & 4.761 \\
\hline 17. & 5.226 & $\sigma\left(\Delta y_{2}\right)$ & 3.980 & 5.298 & 3.963 & 5.191 \\
\hline
\end{tabular}

Note: Productivity growth parameters for country 1 are set to United States estimates and country 2 parameters are set to Japan estimates. Statistics are computed from a simulation of the model for 50,000 periods. The currency risk premium is from shorting the Japanese yen and going long the U.S. dollar. The currency risk premium and the carry trade excess return are stated in percent per annum. $\mu(\bullet)$ denotes a mean value, $\rho(\bullet)$ denotes a correlation value, and $\sigma(\bullet)$ denotes a standard deviation value.

In column 3, Japan's monetary policy is relatively more accommodating to inflation. This is destabilizing (line 17), which jacks up the average currency risk premium (line 6). The forward premium anomaly is quite strong with $\beta_{\text {Fama }}=-4.613$. In column 4, Japan's monetary policy is both relatively more accommodating to inflation and relatively more procyclical. Except for showing a forward premium anomaly, this largely looks like the economy in column 2 .

Finally, in column 5, we set Japan's monetary policy parameters equal to estimated values from the literature. We draw upon Miyazawa (2011), who surveys estimates of the Taylor rule in Japan. Across seven studies, the averages are $\xi=2.06$ and $\zeta=0.43$. Here, Japan becomes the relatively more volatile country (lines 16 and 17). There is a forward premium bias, but no forward premium anomaly. There is a modest mean carry trade excess return and a mean currency risk premium of 1.481 percent per annum. 


\subsection{Impulse Response Functions}

Our paper pushes beyond the existing literature primarily in two dimensions. The first is our consideration of three export pricing conventions, LCP, PCP, and DCP. Typically, the literature has considered export pricing conventions separately. The second dimension is in modeling productivity growth as a long-run risk (LRR) and stochastic volatility (SV) process. In this section, we present impulse response functions to better understand the contributions of these aspects of the model, where we continue to refer to country 1 as the United States and country 2 as Japan.

Figure 3: Output Responses to Positive United States Shocks - Symmetric Monetary Policy and Productivity Growth and DCP
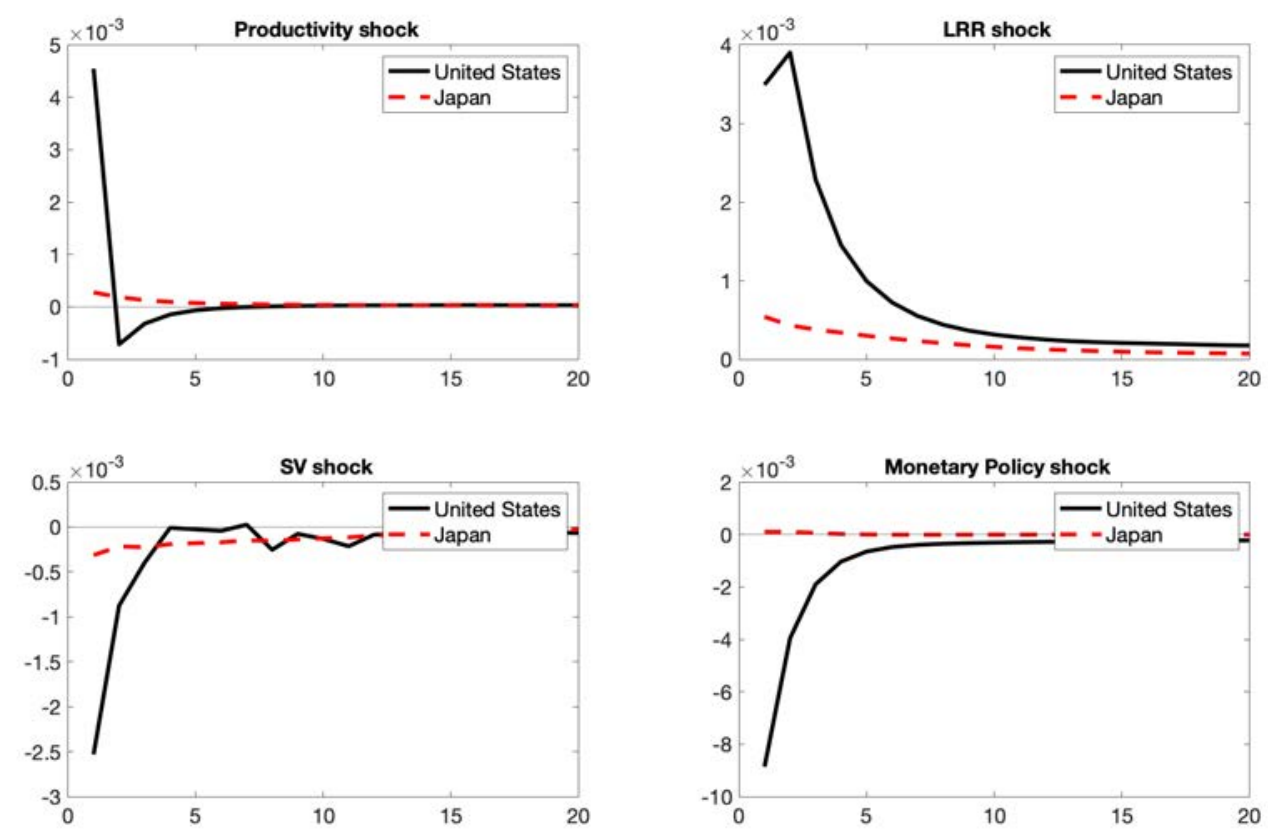

Note: The monetary policy settings are $\xi=1.5$ and $\zeta=0.5$ for both the United States (country 1) and Japan (country 2). The productivity growth parameters are set to United States estimates for both countries. The productivity shock is the direct shock to productivity growth, the LRR shock is the long-run risk shock, and the SV shock is the stochastic volatility shock.

Figure 3 shows impulse responses of output for the United States (country 1) and Japan (country 2) to the four positive United States shocks under DCP and symmetric monetary policy and productivity growth (corresponding to column 3 in Table 3). Notice that the effects on Japan's output from United States shocks are tiny relative to the effects on output in the United States. A positive United States productivity growth (direct) shock raises output in both countries, which 
is a well known result. A positive United States long-run risk (LRR) shock leads to persistent increases in output in both countries. A positive United States stochastic volatility (SV) shock (increasing uncertainty) leads to output contractions in both countries. Qualitatively, the positive United States stochastic volatility shock is similar to a positive United States monetary policy shock.

Figure 4: Inflation Responses to Positive United States Shocks - Symmetric Monetary Policy and Productivity Growth and DCP
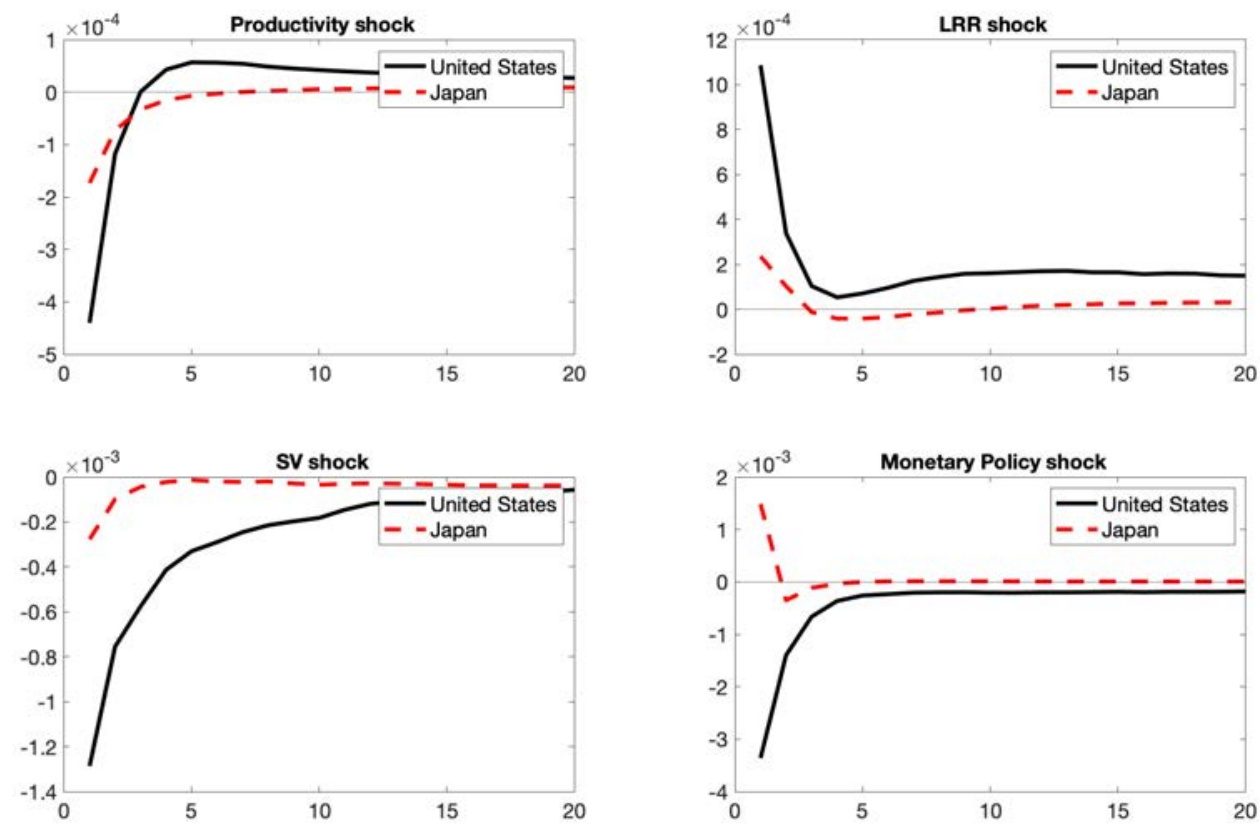

Note: The monetary policy settings are $\xi=1.5$ and $\zeta=0.5$ for both the United States (country 1) and Japan (country 2). The productivity growth parameters are set to United States estimates for both countries. The productivity shock is the direct shock to productivity growth, the LRR shock is the long-run risk shock, and the $\mathrm{SV}$ shock is the stochastic volatility shock.

Figure 4 shows inflation impulse responses for the United States and Japan to the four positive United States shocks under DCP and symmetric monetary policy and productivity growth. Looking at both Figures 3 and 4 , stochastic volatility shocks (uncertainty shocks) in our model have an interpretation as aggregate demand shocks, as in $\mathrm{Xu}(2016)$ and Leduc and Liu (2016). The positive United States stochastic volatility (SV) shock depresses output and inflation. Somewhat more novel is that the long-run risk (LRR) shock also has the interpretation as an aggregate demand shock since the positive United States long-run risk shock leads to sustained increases in both output and inflation. A positive United States monetary policy shock is contractionary and 
leads to deflation in the United States. However, under DCP, it leads to inflation in Japan due to the depreciation of Japan's currency, which increases Japan's import prices.

Figure 5 displays impulse responses of consumption to output ratios for the United States and Japan to the four positive United States shocks under DCP and symmetric monetary policy and productivity growth. This provides some insight to precautionary saving responses. A positive United States productivity growth (direct) shock lowers the ratio in the United States and raises it in Japan, which is facilitated by a trade surplus in the United States. The positive United States long-run risk (LRR) shock raises the ratio in the United States while the positive United States stochastic volatility (SV) shock lowers the ratio in the United States. Again, these patterns are consistent with long-run risk and stochastic volatility shocks being interpreted as aggregate demand shocks. The monetary policy shocks act as aggregate demand shocks.

Figure 5: Consumption to Output Ratio Responses to Positive United States Shocks - Symmetric Monetary Policy and Productivity Growth and DCP
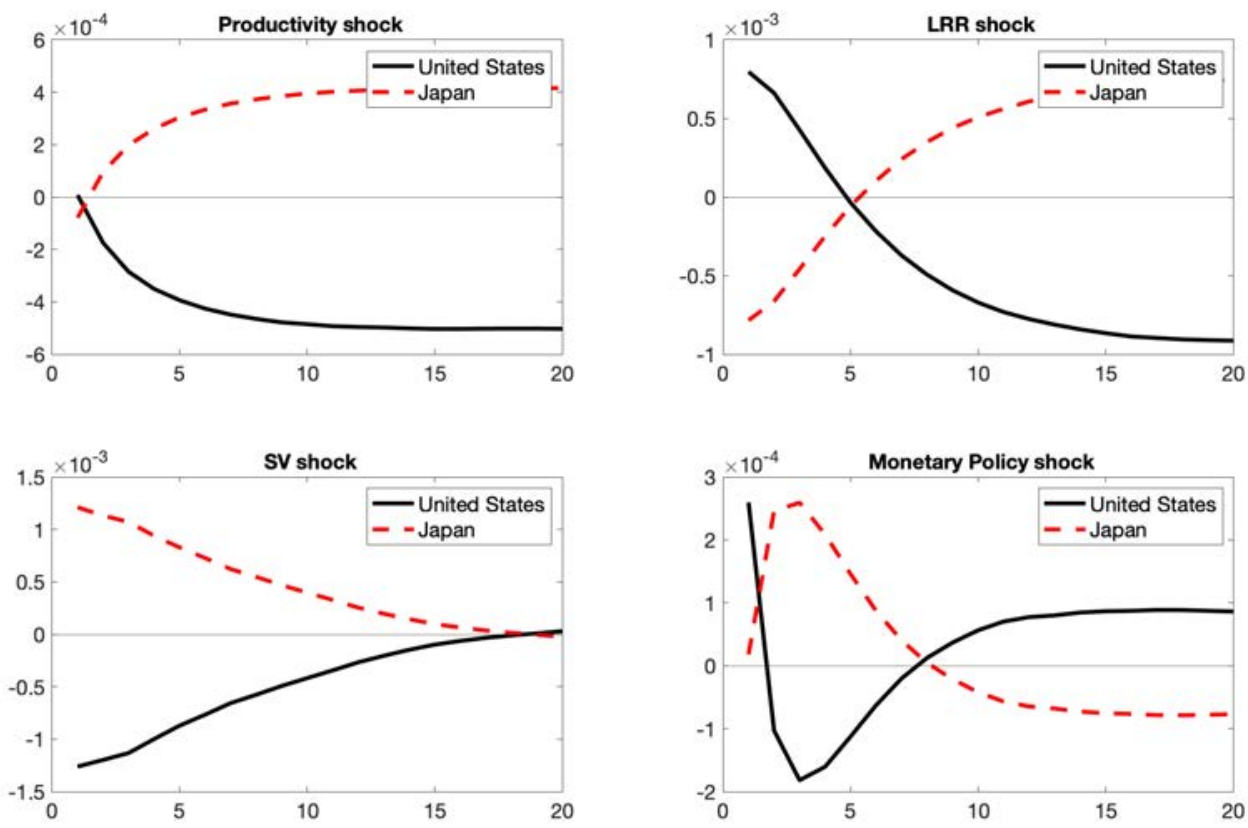

Note: The monetary policy settings are $\xi=1.5$ and $\zeta=0.5$ for both the United States (country 1) and Japan (country 2). The productivity growth parameters are set to United States estimates for both countries. The productivity shock is the direct shock to productivity growth, the LRR shock is the long-run risk shock, and the SV shock is the stochastic volatility shock.

Figure 6 shows impulse responses of the interest rate differential $\left(i_{1, t}-i_{2, t}\right)$ and the currency risk premium $\left(\mathrm{E}_{t}\left(i_{1, t}-i_{2, t}-\Delta \ln \left(S_{1,2, t+1}\right)\right)\right)$ to the four positive United States shocks under 
DCP and symmetric monetary policy and productivity growth. The scale for the currency risk premium is on the right and the scale for the interest rate differential is on the left. The currency risk premium response mimics the interest rate differential $\left(\beta_{\text {Fama }}=0.768\right.$ in this case), but with a much smaller magnitude. The interest rate differential response largely mimics the interest rate response in the United States as the transmission effects from United States shocks to Japan's interest rate are quite small. Stochastic volatility (SV) shocks make the largest contribution to the currency risk premium volatility. In the variance decomposition, the combined United States and Japan stochastic volatility shocks account for 80 percent of the currency risk premium's variance.

Figure 6: Interest Rate Differential and Currency Risk Premium Responses to Positive United States Shocks - Symmetric Monetary Policy and Productivity Growth and DCP
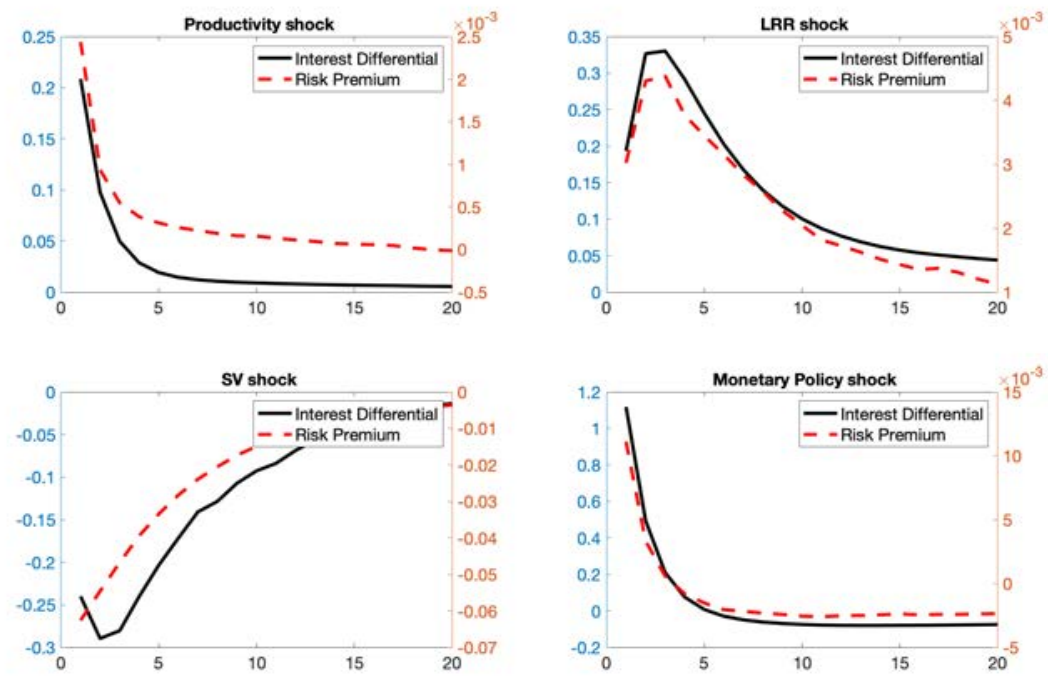

Note: The monetary policy settings are $\xi=1.5$ and $\zeta=0.5$ for both the United States (country 1) and Japan (country 2). The productivity growth parameters are set to United States estimates for both countries. The scale for the currency risk premium $\left(\mathrm{E}_{t}\left(i_{1, t}-i_{2, t}-\Delta \ln \left(S_{1,2, t+1}\right)\right)\right)$ is on the right and the scale for the interest rate differential $\left(i_{1, t}-i_{2, t}\right)$ is on the left. The productivity shock is the direct shock to productivity growth, the LRR shock is the long-run risk shock, and the SV shock is the stochastic volatility shock.

When Does Export Pricing Matter?: The choice amongst DCP, LCP, and PCP matters most for international trade variables in response to monetary policy shocks. Perhaps, this is why Gopinath et al. (2020)'s paper on DCP concentrates on monetary policy. We find the impulse responses to the other shocks are qualitatively similar across the export pricing conventions and are not shown. Notably, export pricing conventions do not have a significant effect on international risk and currency risk premiums. 
Figure 7 shows the terms of trade and the balance of trade impulse responses to positive United States monetary policy shocks under LCP, PCP, and DCP and symmetric monetary policy and productivity growth. We define the terms of trade (TOT) as the price of exports over the price of imports for the United States. The balance of trade (BOT) is similarly defined from the perspective of the United States. The terms of trade and the balance of trade responses to monetary policy shocks under PCP are reversed under LCP. Not surprisingly, since DCP is a combination of LCP and PCP, the terms of trade and the balance of trade responses lie between the LCP and PCP responses.

Figure 7: Comparing LCP, PCP, and DCP Responses to Positive United States Monetary Policy Shocks - Symmetric Monetary Policy and Productivity Growth
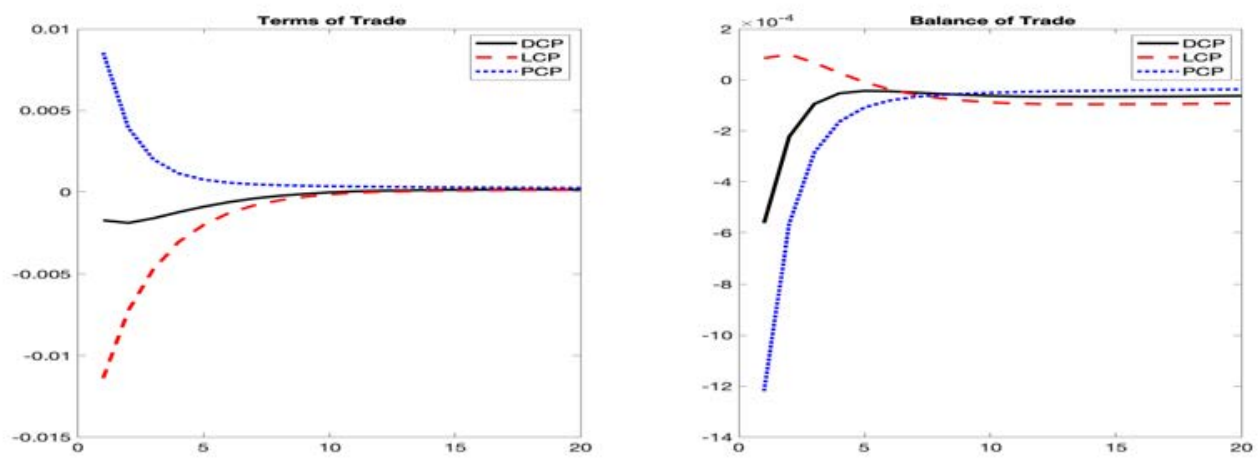

Note: The monetary policy settings are $\xi=1.5$ and $\zeta=0.5$ for both the United States (country 1) and Japan (country 2). The productivity growth parameters are set to United States estimates for both countries. The terms of trade and the balance of trade are from the perspective of the United States.

Although the currency in which export prices are set does not affect the average size of the currency risk premium or the forward premium bias, it does have an effect on the dynamical response to monetary policy shocks. Under PCP, and to a lesser extent DCP, the United States monetary policy shock depresses United States precautionary saving $(\mathrm{BOT}<0)$ which turns the currency risk premium negative (Japan pays). Under LCP, the opposite happens.

Significance of Asymmetries for Currency Risk. Finally, we compare impulse responses of the interest rate differential and the currency risk premium to Japan shocks under the symmetric monetary policy and productivity growth model (Table 3, column 3) and the asymmetric monetary policy and productivity growth model (Table 6, column 3). These impulse responses are shown in Figure 8 , 
Figure 8: Interest Rate Differential and Currency Risk Premium Responses to Positive Japan Shocks - Symmetric and Asymmetric Monetary Policy and Productivity Growth
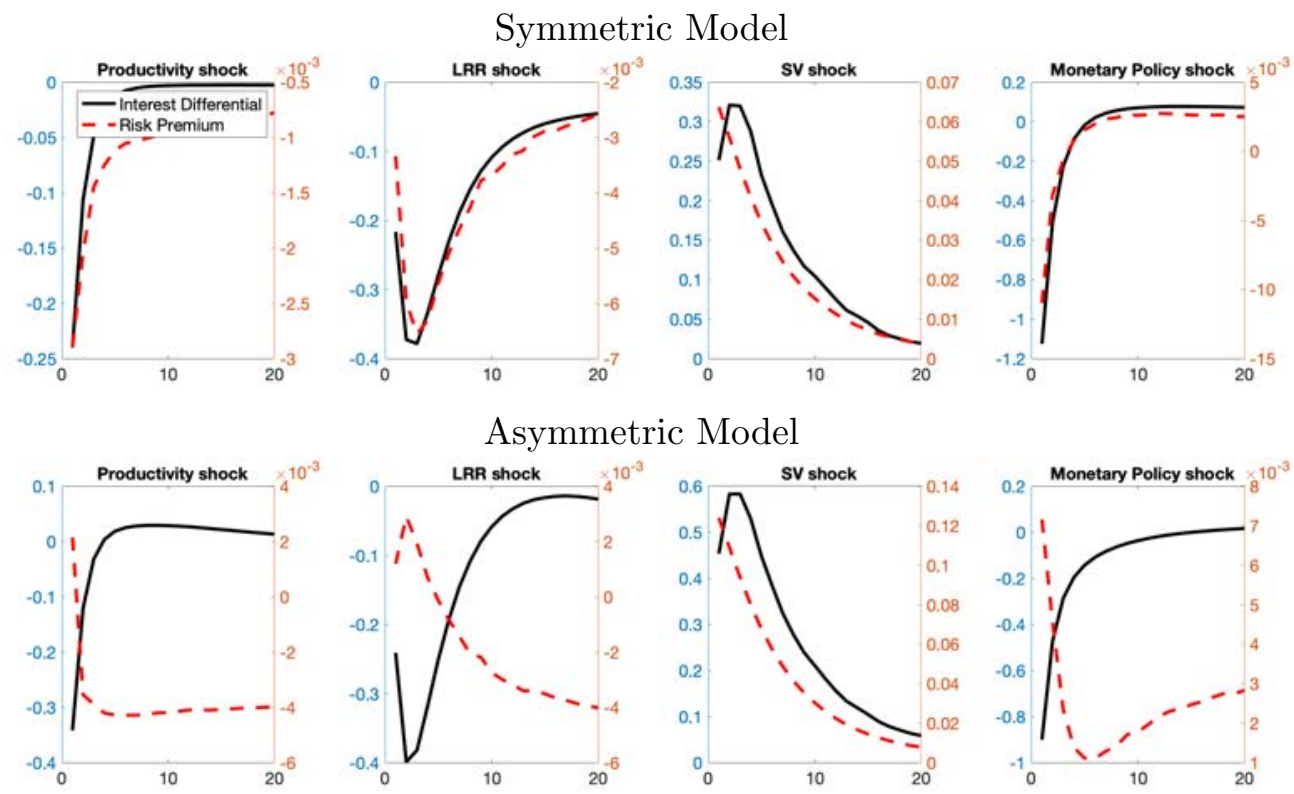

Note: Under the symmetric model, the monetary policy settings are $\xi=1.5$ and $\zeta=0.5$ for both the United States (country 1) and Japan (country 2) and the productivity growth parameters are set to United States estimates for both countries. Under the asymmetric model, the monetary policy parameters and the productivity growth parameters for country 1 are set to United States estimates and for country 2 are set to Japan estimates (Table 6 . column 3). The scale for the currency risk premium $\left(\mathrm{E}_{t}\left(i_{1, t}-i_{2, t}-\Delta \ln \left(S_{1,2, t+1}\right)\right)\right)$ is on the right and the scale for the interest rate differential $\left(i_{1, t}-i_{2, t}\right)$ is on the left. The productivity shock is the direct shock to productivity growth, the LRR shock is the long-run risk shock, and the SV shock is the stochastic volatility shock.

The impulse responses of the interest rate differential are similar under the symmetric and asymmetric models. Except in response to the stochastic volatility (SV) shock, cross-country heterogeneity in productivity growth and monetary policy, changes the response of the currency risk premium significantly. For these shocks, a negative correlation between the currency risk premium and interest rate differential can be inferred from the impulse responses, which corresponds to a $\beta_{\text {Fama }}=-4.613$ in the asymmetric case.

\subsection{Limitations of the Model}

While the goal of this project is not to develop a model that is quantitatively accurate in every dimension, we would be remiss if we did not point out some of the limitations of our model. Table 7 compares additional moments from the data to the model with heterogeneous productivity and monetary policy parameters for Japan set to estimates reported in the literature. 
Table 7: Additional Data and Model Moments

\begin{tabular}{lrr}
\hline \hline & Data & Model \\
\hline$\mu\left(\pi_{1}\right)$ & 3.487 & 4.045 \\
$\mu\left(\pi_{2}\right)$ & 1.368 & 3.546 \\
$\mu\left(i_{1}\right)$ & 5.252 & 5.984 \\
$\mu\left(i_{2}\right)$ & 2.664 & 4.005 \\
$\mu\left(r_{1}\right)$ & 1.765 & 1.948 \\
$\mu\left(r_{2}\right)$ & 1.296 & 0.460 \\
$\sigma\left(\pi_{1}\right)$ & 3.004 & 1.974 \\
$\sigma\left(\pi_{2}\right)$ & 3.136 & 2.197 \\
$\sigma\left(\Delta y_{1}\right)$ & 4.503 & 4.761 \\
$\sigma\left(\Delta y_{2}\right)$ & 6.354 & 5.191 \\
$\sigma\left(\Delta c_{1}\right)$ & 3.043 & 4.793 \\
$\sigma\left(\Delta c_{2}\right)$ & 5.922 & 5.213 \\
$\sigma\left(\Delta \ln \left(S_{1,2}\right)\right)$ & 24.648 & 7.194 \\
$\sigma\left(\Delta \ln \left(Q_{1,2}\right)\right)$ & 24.791 & 5.250 \\
$\rho\left(\Delta \ln \left(Q_{1,2}\right), \Delta \ln \left(S_{1,2}\right)\right)$ & 0.989 & 0.936 \\
\hline \hline
\end{tabular}

Notes: Model specification is from column 5 in Table 6. Productivity parameters are set to estimated values for the United States (country 1) and Japan (country 2) with Japan monetary policy parameters set to estimated values reported in the literature. $\mu(\bullet)$ denotes a mean value, $\sigma(\bullet)$ denotes a standard deviation value, and $\rho(\bullet)$ denotes a correlation value. Means and standard deviations are annualized. Exchange rate data are from FRED. Not seasonally adjusted data on consumption and GDP are from Datastream. Sample is 1976Q1 to 2020Q1, except for consumption volatility which due to availability for Japan, runs from 1994Q1 to 2019Q4. Moments from the model are from simulation over 50,000 periods.

The mean values of inflation and interest rates from the model do a reasonable job of describing the mean values from the data. The model mildly overstates output and consumption growth volatility for the United States (country 1) and mildly understates for Japan (country 2). Where the model falls short is in explaining exchange rate volatility (and to a lesser extent, inflation volatility). The model is able to generate a very high correlation between real and nominal exchange rate depreciation.

\section{Conclusion}

We show in a two-country DSGE model under incomplete markets how the currency risk premium and the forward premium bias/anomaly depend on the extent of cross-country heterogeneity. The model features recursive utility and productivity growth exhibiting long-run risk with stochastic volatility. The primary mechanism behind the currency risk premium lies in the relative strength of the precautionary saving motive across countries. If people of Japan have a stronger precautionary saving motive, the people in the United States must be incentivized to borrow to satisfy Japan's saving motive. The result is a positive currency risk premium from going long the U.S. 
dollar and short the Japanese yen.

Our main results are as follows. First, we find if country 2 (Japan) has a relatively more procyclical monetary policy and productivity growth is symmetric across countries, country 2 will pay the currency risk premium. This result is in line with Backus et al. (2020). Second, if country 2 is more accommodating towards inflation, country 1 (United States) pays the risk premium. This result runs contrary to Backus et al. (2020). Third, what is potentially more important for currency risk, is cross-country productivity growth heterogeneity. While relative output volatility is not a sufficient statistic, the currency risk premium paid by country 1 appears to be decreasing in the difference between country 1 and country 2 output growth volatility. Fourth, the export pricing convention (LCP, PCP, DCP) is unimportant in the determination of the unconditional mean of the currency risk premium and the forward premium bias/anomaly, but can have an impact on the dynamic response of the risk premium to monetary policy shocks. Fifth, stochastic volatility (uncertainty) shocks and long-run risk shocks can be viewed as aggregate demand shocks. Sixth, stochastic volatility shocks make a large contribution to risk premium volatility, but are not helpful in explaining the forward premium bias/anomaly. 


\section{References}

Backus, D. K., S. Foresi, And C. I. Telmer (2001): “Affine Term Structure Models and the Forward Premium Anomaly," Journal of Finance, 56, 279-304.

Backus, D. K., F. Gavazzoni, C. Telmer, and S. E. Zin (2020): "Monetary Policy and the Uncovered Interest Rate Parity Puzzle," Journal of Finance, forthcoming.

Backus, D. K., P. J. Kehoe, and F. E. Kydland (1992): "International Real Business Cycles," Journal of Political Economy, 100, 745-775.

Backus, D. K. And G. W. Smith (1993): "Consumption and Real Exchange Rates in Dynamic Economies with Non-Traded Goods," Journal of International Economics, 35, 297-316.

Bansal, R. And I. Shaliastovich (2012): "A Long-Run Risks Explanation of Predictability Puzzles in Bond and Currency Markets," Review of Financial Studies, 26, 1-33.

Bansal, R. And A. Yaron. (2004): "Risks for the Long Run: A Potential Resolution of AssetPricing Puzzles," Journal of Finance, 59, 1481-1509.

Benigno, G., P. Benigno, and S. Nistico (2012): "Risk, Monetary Policy and the Exchange Rate," NBER Macroeconomics Annual, 26, 247-309.

Berg, K. A. And N. C. MARK (2017): "Measures of Global Uncertainty and Carry-Trade Excess Returns," Journal of International Money and Finance, 88, 212-227.

(2018): "Global Macro Risks in Currency Excess Returns," Journal of Empirical Finance, $45,300-315$.

(2019): "Where's the Risk? The Forward Premium Bias, the Carry-Trade Premium, and Risk-Reversals in General Equilibrim," Journal of International Money and Finance, 95, $297-316$.

Betts, C. And M. Devereux (2000): "Exchange Rate Dynamics in a Model of Pricing to Market," Journal of International Economics, 50, 215-244.

Bilson, J. F. O. (1981): "The Speculative Efficiency Hypothesis," Journal of Business, 54, $435-451$.

Brandt, M. W., J. H. Cochrane, And P. Santa-Clara (2006): "International Risk Sharing is Better than You Think, or Exchange Rates Are Too Smooth," Journal of Monetary Economics, 53, 671-698.

Calvo, G. A. (1983): "Staggered Prices in a Utility-Maximizing Framework," Journal of Monetary Economics, 12, 393-398. 
Colacito, R., M. Croce, F. Gavazzoni, and R. C. Ready (2018a): "Currency Risk Factors in a Recursive Multicountry Economy," Journal of Finance, 73, 2719-2756.

Colacito, R., M. Croce, S. Ho, and P. Howard (2018b): "BKK the EZ Way: International Long-Run Growth News and Capital Flows," American Economic Review, 108, 3416-3449.

David, J. M., E. Henriksen, And I. Simonovska (2016): "The Risky Capital of Emerging Markets," mimeo, UC Davis.

Epstein, L. G. And S. E. Zin (1989): "Substitution, Risk Aversion, and the Temporal Behavior of Consumption and Asset Returns: A Theoretical Framework," Econometrica, 57, 937-969.

FAma, E. F. (1984): "Forward and Spot Exchange Rates," Journal of Monetary Economics, 14, $319-338$.

Fernández-Villeverde, J. And P. A. Guerrón-Quintana (2020): "Uncertainty Shocks and Business Cycle Research," NBER Working Paper $26768,9$.

Fleming, J. M. (1962): "Domestic Financial Policies under Fixed and Floating Exchange Rates," Staff Papers, International Monetary Fund, 9, 369-380.

Froot, K. And R. Thaler (1990): "Anomalies: Foreign Exchange," Journal of Economic Perspectives, 4, 179-192.

Gopinath, G., E. B. andCamila Casas, F. Diez, P.-O. Gourinchas, and M. PlagborgMoller (2020): "Dominant Currency Paradigm," American Economic Review, 110, 677-719.

Gourio, F., M. Siemer, And A. Verdelhan (2013): "International Risk Cycles," Journal of International Economics, 89, 471-484.

Hassan, T. A. And R. C. Mano (2019): "Forward and Spot Exchange Rates in a Multi-currency World," Quarterly Journal of Economics, 134, 397-450.

Hodrick, R. J. And E. C. Prescott (1997): "Postwar U.S. Business Cycles: An Empirical Investigation," Journal of Money, Credit and Banking, 29, 1-16.

Hodrick, R. J. And S. SRIvastava (1984): "An Investigation of Risk and Return in Forward Foreign Exchange," Journal of International Money and Finance, 3, 5-29.

Kollmann, R. (2016): "International Business Cycles and Risk Sharing with Uncertainty Shocks and Recursive Utility," Journal of Economic Dyanamics $\&$ Control, 72, 94-97.

(2019): "Explaining International Business Cycle Synchronization: Recursive Preferences and the Terms of Trade Channel," Open Economies Review, 30, 65-85. 
Leduc, S. And Z. Liu (2016): "Uncertainty Shocks are Aggregate Demand Shocks," Journal of Monetary Economics, 82, 20-35.

Lustig, H., N. Roussanov, and A. Verdelhan (2011): "Common Risk Factors in Currency Markets," Review of Financial Studies, 24, 3731-3777.

Lustig, H. And A. Verdelhan (2007): "The Cross Section of Foreign Currency Risk Premia and Consumption Growth Risk," American Economic Review, 97, 89-117.

Menkhoff, L., lucio Sarno, M. Schmeling, and A. Schrimpf (2012): "Carry Trades and Global Foreign Exchange Volatility," Journal of Finance, 67, 682-718.

Miyazawa, K. (2011): “The Taylor Rule in Japan,” Japanese Economy, 38, 79-104.

Mumtaz, H. And K. Theodoridis (2017): "Common and Country Specific Economic Uncertainty," Journal of International Economics, 105, 205-216.

Mundell, R. A. (1963): "Capital Mobility and Stabilization Policy under Fixed and Flexible Exchange Rates," Candian Jounal of Economics and Political Science, 29, 475-485.

Obstfeld, M. And K. Rogoff (1995): "Exchange Rate Dynamics Redux," Journal of Political Economy, 204, 624-660.

Ready, R., N. Roussnaov, and C. Ward (2017): "After the Tide: Commodity Currencies and Global Trade," Journal of Monetary Economics, 85, 69-86.

Schmitt-Grohe, S. And M. Uribe (2003): "Closing Small Open Economy Models," Journal of International Economics, 61, 163-185.

Swanson, E. (2019): "A Macroeconomic Model of Equities and Real, Nominal, and Defautable Debt," University of California, Irvine, Mimeo.

Tretvoll, H. (2018): "Real Exchange Rate Variability in a Two-Country Business Cycle Model," Review of Economic Dynamics, 27, 123-145.

WeIL, P. (1989): "The Equity Premium Puzzle and the Risk-Free Rate Puzzle," Journal of Monetary Economics, 24, 401-421.

XU, S. (2016): "Interpreting Volatility Shocks as Preference Shocks," Economics Letters, 149, 135-49. 